\title{
Comorbidities and inflammation associated with ovarian cancer and its influence on SARS-CoV-2 infection
}

Sima Chaudhari', Satyajit Dey Pereira', Meshach Asare-Warehene², Ritam Naha', Shama Prasada Kabekkodu', Benjamin K. Tsang ${ }^{2}$ and Kapaettu Satyamoorthy ${ }^{1 *}$ (I)

\begin{abstract}
Coronavirus disease 2019 (COVID-19) caused by the novel severe acute respiratory syndrome coronavirus 2 (SARSCoV-2) worldwide is a major public health concern. Cancer patients are considered a vulnerable population to SARS-CoV-2 infection and may develop several COVID-19 symptoms. The heightened immunocompromised state, prolonged chronic pro-inflammatory milieu coupled with comorbid conditions are shared in both disease conditions and may influence patient outcome. Although ovarian cancer (OC) and COVID-19 are diseases of entirely different primary organs, both diseases share similar molecular and cellular characteristics in their microenvironment suggesting a potential cooperativity leading to poor outcome. In COVID-19 related cases, hospitalizations and deaths worldwide are lower in women than in males; however, comorbidities associated with OC may increase the COVID-19 risk in women. The women at the age of 50-60 years are at greater risk of developing OC as well as SARS-CoV-2 infection. Increased levels of gonadotropin and androgen, dysregulated renin-angiotensin-aldosterone system (RAAS), hyper-coagulation and chronic inflammation are common conditions observed among OC and severe cases of COVID-19. The upregulation of common inflammatory cytokines and chemokines such as tumor necrosis factor a (TNF-a), interleukin (IL)-1 $\beta, I L-2, I L-6, I L-10$, interferon- $\gamma$-inducible protein 10 (IP-10), granulocyte colony-stimulating factor (G-CSF), monocyte chemoattractant protein-1 (MCP-1), macrophage colony-stimulating factor (M-CSF), among others in the sera of COVID-19 and OC subjects suggests potentially similar mechanism(s) involved in the hyper-inflammatory condition observed in both disease states. Thus, it is conceivable that the pathogenesis of OC may significantly contribute to the potential infection by SARS-CoV-2. Our understanding of the influence and mechanisms of SARS-CoV-2 infection on OC is at an early stage and in this article, we review the underlying pathogenesis presented by various comorbidities of OC and correlate their influence on SARS-CoV-2 infection.
\end{abstract}

Keywords: Ovarian cancer, risk factor, SARS-CoV-2, Inflammation, Hormones

\footnotetext{
* Correspondence: ksatyamoorthy@manipal.edu

'Department of Cell and Molecular Biology, Manipal School of Life Science, Manipal Academy of Higher Education, Manipal, Karnataka 576104, India

Full list of author information is available at the end of the article
} 


\section{Introduction}

Since the first case reported in December 2019, coronavirus disease 2019 (COVID-19) has spread globally, resulting in the ongoing pandemic. Interestingly, the phenotypic symptoms of infected individuals are multi-systemic and diverse. While many display mild symptoms, some remain asymptomatic and may act as carriers. However, subgroups of the infected population may present severe phenotypes with acute respiratory distress and/or multi-organ failure [97]. These subgroups of patients exhibit comorbidities such as hypertension, diabetes, cardiovascular disease and respiratory disease [203]. The initial observation of poor outcome of cancer patients upon infection by severe acute respiratory syndrome coronavirus 2 (SARS$\mathrm{CoV}-2$ ), emphasises their increased risk. The immunocompromised state of cancer patients either because of the tumor pathophysiology or anticancer treatment was proposed as a contributing factor for enhanced susceptibility [102, 208]. However, cancer includes an assorted array of tumor of various organs and a recent study by Lee et al. [97] reported varied susceptibility of SARS-CoV2 to different types of tumors [97]. Nonetheless, the mortality in cancer patients from COVID-19 is significantly correlated with gender, age and comorbidities rather than immunosuppression [96]. The comorbid conditions associated with COVID-19 mediates the hyper-inflammatory microenvironment that results in increased severity of the disease. In a study reported by Spezzani et al. [172] an immunocompromised metastatic breast cancer patient with COVID-19 had a quicker recovery time compared with an immunocompetent hypertensive COVID-19 patient, suggesting that comorbidities associated with hyperproduction of cytokines are the key drivers of COVID-19 severity and hospitalization [96, 97, 172]. Age-related ovarian cancer (OC) and its associated comorbidities share similar molecular and cellular characteristics with the microenvironment of COVID-19 patients. Increased levels of gonadotropin and androgen $[21,46,110]$ as well as dysregulated renin-angiotensin-aldosterone system (RAAS) are commonly reported in $\mathrm{OC}$ and severe cases of COVID-19. Additionally, inflammatory cytokines and chemokines such as interleukin (IL)-1 $\beta$, IL-2, IL-5, IL-6, IL-7, IL-8, IL-10, tumor necrosis factor $\alpha$ (TNF- $\alpha$ ), granulocyte colony-stimulating factor (G-CSF), vascular endothelial growth factor (VEGF), basic fibroblast growth factors (bFGF), macrophage colony-stimulating factor (M-CSF), growth-regulated oncogene alpha (GRO- $\alpha)$, interferon- $\gamma$ inducible protein 10 (IP-10), eotaxin, monocyte chemoattractant protein-1 (MCP-1) etc. (Table 1) are significantly upregulated and are common to both disease conditions. Further, hyper-inflammation and hypercoagulation states appear to be common among these two conditions [114, 165]. These shared microenvironments suggest an increased risk of infection and severity of infection in OC subjects or altered risk of OC progression due to SARS-CoV-2.

\section{Ovarian cancer}

Ovarian cancer (OC) emerges from the ovaries [27] and/ or the fallopian tube [95] with approximately $90 \%$ developing from the ovarian surface epithelium [27]. Based on their microscopic features, the epithelial ovarian cancers (EOCs) are further subtyped as serous (68-71\%), mucinous (3\%), endometrioid (9-11\%), clear cell (1213\%), malignant Brenner (1\%), and undifferentiated (6\%) [183]. Using molecular characterization, EOCs are grouped into type I and type II cancers [184]. Mutations in oncogenes and tumour suppressor gene such as KRAS, BRAF, PTEN, PIK3CA, and ARID1A are relatively common in type I EOCs [161, 184]; however, mutations in $p 53$ are frequently reported in type II EOCs [138].

\section{Prevalence of ovarian cancer}

$\mathrm{OC}$ is the most lethal gynaecological cancer predominantly due to late diagnosis, recurrence and chemoresistance $[120,134]$. In 2018, the estimated agestandardized incidence and mortality rate of OC was 6.6 and 3.9 per 100,000 women respectively [17]. Transvaginal ultrasound coupled with CA125 detection are the conventional means of screening OC; however, their low-test accuracy present as a major setback in their clinical application [47, 207]. Although plasma gelsolin has shown promise as an early diagnostic biomarker in a smaller cohort of OC patients [8], it is yet to be validated in a larger cohort. This leans to the global efforts of developing novel diagnostic biomarkers to help in the early diagnosis of OC.

Table 1 Significantly upregulated cytokines and chemokines in the serum of ovarian cancer and COVID-19 patients

\begin{tabular}{|c|c|c|c|}
\hline & $\begin{array}{l}\text { Immune } \\
\text { mediators }\end{array}$ & Profile & References \\
\hline \multirow[t]{2}{*}{ COVID-19 } & $\begin{array}{l}\text { Cytokines/ } \\
\text { Growth Factors }\end{array}$ & $\begin{array}{l}\text { TNF-a, IL-1a, IL-1ß, IL-2, IL-4, IL-5, IL-6, IL-7, IL-10, IL-12p40, IL-13, IL-16, IL-18, IFN-a2, IFN-y, TRAIL, } \\
\text { MIF, LIF, VEGF, SCGF, G-CSF, M-CSF, SCF, HGF, bFGF }\end{array}$ & $\begin{array}{l}{[200,201,105,106,} \\
76,203,101]\end{array}$ \\
\hline & Chemokines & GRO-a, IL-8, MIG, IP-10, Eotaxin, CTACK, SDF-1a, MCP-1, MIP-1a, MCP-3 & \\
\hline \multirow[t]{2}{*}{$\begin{array}{l}\text { Ovarian } \\
\text { cancer }\end{array}$} & $\begin{array}{l}\text { Cytokines/ } \\
\text { Growth Factors }\end{array}$ & TNF-a, IL-1 $\beta$, IL-2, IL-5, IL-6, IL-7, IL-9, IL-10, VEGF, G-CSF, M-CSF, PIGF, PDGF-BB, bFGF & {$[60,202]$} \\
\hline & Chemokines & GRO-a, IL-8, IP-10, Eotaxin, MCP-1, MIP-1 $\beta$, RANTES & \\
\hline
\end{tabular}




\section{Ovarian cancer risk factors and morbidities}

$\mathrm{OC}$ is a multifactorial disease, and its diverse epidemiological characteristics are responsible for the disparities in its incidences across the world. Various comorbid conditions linked to $\mathrm{OC}$ include demographic, reproductive, gynaecologic, hormonal, genetic, and lifestyle factors. In addition, $\mathrm{OC}$ is linked with a plethora of risk factors including but not limited to age, obesity, unhealthy meals, smoking, alcoholism, early menarche, late menopause, null parity, hormone replacement therapy, mutations in $B R A C 1 / 2$, and family history (Table 2) [134].

\section{Ovarian cancer and basis for pathogenesis}

Multiple risk factors are associated with OC; however, the underlying mechanism of pathogenesis remains to be fully understood. Based on evidence, several theories have been proposed which are - a) the incessant ovulation theory $[44]$, b) retrograde menstruation theory [162], c) the gonadotropin theory [34] and d) the inflammation theory [140]. Among these, the gonadotropin and inflammatory theories are the most extensively explored.

\section{Gonadotropin theory}

Cramer and Welch in 1983 introduced the hypothesis of gonadotropin and suggested that a higher level of gonadotrophin may contribute to the pathogenesis of OC; however, the suppression of pituitary gonadotropin secretion may decrease the risk of OC [34]. Endocrine hormones such as follicle stimulating hormone (FSH) and luteinizing hormone (LH), are the important regulators of gametogenesis and steroidogenesis [27]. During ovulation, pregnancy, lactation, or menopause, the levels of these hormones are significantly altered. The damage associated with the rupture of follicle during ovulation resulting from high levels of FSH, LH and estrogen are also risk factors and may lead to OC. The higher levels of progesterone along with minimal estrogen production are associated with increased protection against OC. Prolonged production of progesterone during pregnancy interrupts the ovulatory cycle reducing the frequency of damage caused by ovulation $[27,129,155,160]$. Oral contraceptive pills mostly entail a combination of estrogen and progesterone and act by inhibiting gonadotropin production leading to ovulation suppression [42]. Hormone replacement therapy with estrogen alone fails to improve in the survival of $\mathrm{OC}$ patients but its combination with progesterone reduces the risk of OC [157]. During lactation, the suckling effect limits the secretion of estrogen thereby preventing the normal pulsatile secretion of $\mathrm{LH}$; an effect that result in anovulation [124]. Taken together, these findings suggest that increased gonadotropin production could be possibly implicated in OC pathogenesis.

\section{Inflammation theory}

Inflammatory mediators are crucial for the maintenance of normal physiological homeostasis. However, the

Table 2 Comorbidities and their association with ovarian cancer risk

\begin{tabular}{|c|c|c|c|c|}
\hline Factors & Comorbidities & $\begin{array}{l}\text { Association with ovarian } \\
\text { cancer }\end{array}$ & Mechanism of pathogenesis explained by & References \\
\hline Demographic & Age & Increased risk, Poor outcome & Gonadotropin theory, Inflammation theory & {$[25]$} \\
\hline \multirow[t]{4}{*}{ Reproductive } & Ovulation & Increased risk & Incessant ovulation theory, Inflammation theory & {$[160]$} \\
\hline & Pregnancy & Protective & Gonadotropin theory & [155] \\
\hline & Pre-eclampsia Pregnancy & Increased risk & Inflammation theory & {$[20]$} \\
\hline & Lactation & Protective & Gonadotropin theory & [132] \\
\hline \multirow[t]{3}{*}{ Gynaecologic } & Pelvic inflammatory disease & Increased risk & Inflammation theory & [104] \\
\hline & Endometriosis & Increased risk & $\begin{array}{l}\text { Retrograde menstruation theory, Inflammation } \\
\text { theory }\end{array}$ & [133] \\
\hline & Tubal ligation & Protective & Inflammation theory & [123] \\
\hline \multirow[t]{2}{*}{ Hormonal } & Oral Contraceptive Pills (OCPs) & Protective & Gonadotropin theory & {$[42]$} \\
\hline & $\begin{array}{l}\text { Hormone replacement therapy } \\
\text { (HRT) }\end{array}$ & Controversial & Gonadotropin theory & {$[35]$} \\
\hline \multirow[t]{3}{*}{ Genetic } & Family history & Increased risk & & {$[88]$} \\
\hline & BRCA mutation & Increased risk & & [179] \\
\hline & Lynch syndrome & Increased risk & & [108] \\
\hline \multirow[t]{3}{*}{ Lifestyle } & Food & Controversial & Inflammation theory & {$[146,121]$} \\
\hline & Adiposity/Obesity & Increased risk & Inflammation theory, Gonadotropin theory & [144] \\
\hline & Smoking/ Caffeine & Controversial & Inflammation theory & {$[94,119]$} \\
\hline Environmental & Talc & Increased risk & Inflammation theory & [196] \\
\hline
\end{tabular}


imbalance between pro- and anti-inflammatory mediators may result in self-tissue damage leading to the risk of mutagenesis and aberrant cell growth [1]. Proinflammatory mediators may contribute to ovarian cancer by a) direct effect on tissues promoting transformation and b) indirect effect where the inflammation aid in the migration of malignant cells from other regions within the organ $[167,204]$.

\section{Direct effect}

Epithelial cells, stromal fibroblast, and leukocytes in the female reproductive tract highly express immune components including pattern recognition receptors [toll like receptors (TLRs)] and secreted molecules such as antimicrobial peptides [human neutrophil peptide (HNP1); lysozyme, lactoferrin], cytokines (IL-1, IL-6), and chemokines [CC-chemokine ligand 2 (CCL2)]. These immune components show spatio-temporal variation within the reproductive tract and their distribution is critically altered by the changes in hormone secretion during different stages of the ovulation cycle [197]. In OC, the dysregulated secretion of cytokines such as IL-1, IL-2, IL-6, M-CSF, TNF- $\alpha$ and others [9] as well as elevated tumor necrosis factor receptor 1 (TNFR1) [83] are observed, suggesting contribution of inflammation during tumor progression. Inflammatory cytokines create a microenvironment that promote DNA aberration and mutagenesis (via a nitric oxide dependent mechanism) [81], inactivate the tumor suppressor genes such as $p 53$ and enhance cell proliferation and oncogenesis by the activation of hypoxia-inducible factor 1- alpha (HIF $1 \alpha)$, nuclear factor kappa B (NF-kB), and/or signal transducer and activator of transcription (STAT) 3 pathways [58, $65,69,70,74,77,165,166]$. During ovulation, inflammatory mediators including leukotrienes and prostaglandin as well as vasoactive agents such as bradykinin induces the inflammatory reaction [36].

The association of metabolic disorders such as type 2 diabetes and obesity with poor outcomes of EOC has been lucidly reviewed by Craig et al. [33]. The pathological factors for these observations have been attributed to the altered expression profiles of cytokines and adipokines. Such changes induce altered immune responses towards the proliferation of tumor cells as well as pro-tumorigenic signaling pathways [14, 33, 98]. Women with higher adiposity and a higher level of Creactive protein (CRP) and IL-6 are suggested to be more prone to the incidence of OC [144]. In vitro studies have demonstrated the ability of estrogen to stimulate $\mathrm{B}$ cell response and depletion of suppressor $\mathrm{T}$ cells contributing towards the elevated antibodies and autoantibodies level [118], hence increasing the risk of OC [35]. The increased risk of $\mathrm{OC}$ among the individual with high intake of red meat and processed meat is because of increase in the source of iron, salt, saturated fats, and other factor associated with DNA damage such as heterocyclic amines, nitrosamine and $\mathrm{N}$-nitroso compounds and polycyclic aromatic hydrocarbon $[5,23]$. In contrast, the reduced risk upon consumption of a plantbased diet was associated with a reduction in cancerpromoting hormones [112].

\section{Indirect effect}

Although ovulation has a significant contribution towards the etiology of $\mathrm{OC}$, the incidence of EOC is higher in the women of 63 years old who have attained menopause [55]. During post-menopause, the ovarian follicles are predominantly depleted with the remaining ovary being reduced to collagenous scar tissue [86]. The migration of malignant cells from oviduct to ovary via cytokine/chemokine gradient formed from the surface of the wounded ovary potentially explains why menopause women are at a higher risk of OC [86, 204]. This phenomenon might also explain the protective effect of hysterectomy and tubal ligation [62, 86] against the development of OC.

\section{SARS-CoV-2 and Inflammation}

SARS-CoV-2 is a novel coronavirus which causes COVID-19, a disease that has been denoted pandemic globally by the World Health Organisation (WHO). SARSCoV-2 shares about $80 \%$ genomic similarity with SARS$\mathrm{CoV}$ which was responsible for a respiratory disease outbreak in 2003 [24]. As of $28^{\text {th }}$ January 2021, the WHO had reported 99,864,391 confirmed COVID-19 cases and 2,149,700 deaths worldwide [199].

Most of our current understanding of inflammatory effects of SARS-CoV-2 comes from several studies related to lung injury and respiratory distress. SARS viruses cause acute respiratory distress syndrome (ARDS) and acute lung injury (ALD). The alveolar cavities of SARS patients contain desquamated epithelial cells, some of which are large and consist of syncytial nuclei [66]. The syncytial nuclei represent the cytopathogenic effect caused by viral replication in the cells [164]. Immunostaining of pulmonary interstitial tissues demonstrates the infiltration of monocytes, lymphocyte, and macrophages, fibrin deposition, formation of the hyaline membrane, and fibrinosis of alveolar extrude. Besides, ACE2 expressing cells infected with SARS-CoV demonstrated a higher level of transforming growth factor-beta 1 (TGF- $\beta 1$ ) and MCP-1 with moderate levels of IL-1 $\beta$, IL- 6 , and TNF- $\alpha$. Thus, the histological changes and the upregulation of proinflammatory cytokines in the cells of patient with SARS$\mathrm{CoV}$, reconcile the acute lung injury [66]. MCP-1 is a chemotaxis promoting factor which induces macrophages migration towards the affected sites [205]. Upon stimulation with several pro-inflammatory cytokines, macrophage 
undergoes proliferation, or are activated to produce more pro-inflammatory cytokines [143]. TGF- $\beta 1$ enhances Fasmediated cell apoptosis leading to the death of alveolar epithelial cells, an outcome resulting in acute lung injury [64]. Although the production of inflammatory cytokines in SARS-infected cells are initiated for combating the invading virus, the hyper-production of inflammatory cytokines might attack both infected as well as uninfected cells, culminating in significant ARDS and ALD [66]. An increase in pro-inflammatory cytokines has also been observed in other SARS, including acute exacerbation of chronic obstructive pulmonary disease and avian influenza (H5N1), suggesting overexpression of inflammatory cytokine is the common mediator of ALD and ARDS in a patient infected with a virus via respiratory pathway $[26,213]$.

In contrast to non-severe SARS-CoV-2 infected patients, an abundance of cytokines and chemokines such as MCP1, G-CSF, IP10, TNF- $\alpha$, and macrophage inflammatory protein 1alpha (MIP1A) were reported in severe cases [76]. Indeed, among the deceased patient of COVID-19, the level of TNF- $\alpha$, IL-6, IL-1 $\beta$, and IL-8, were the highest when compared to recovered cases [115]. The COVID-19 patient with ARDS also shows increased chemokine receptor 6 (CCR6) $^{+} \mathrm{T}$ helper 17 (Th17) cells which are derived from $\mathrm{CD}^{+} \mathrm{T}$ cells [200, 201]. Th-17 cells induce IL-17, IL-21, IL-22, and GMCSF [111]. There was a significant correlation of IL-17 with the lung injury and is one of the pro-inflammatory cytokines capable of producing a vast number of inflammatory chemokines and cytokines $[18,130]$.

\section{Microenvironment shared by SARS-CoV-2 and OC affected individuals}

Although SARS-CoV-2 and OC affect distinctive primary organs, the molecular signatures in their respective microenvironment seem to be common. This suggests a common mode of pathogenesis and also supports a) the altered risk of the OC progression in COVID-19 patients, b) augmentation of infection by SARS-CoV-2 in $\mathrm{OC}$ patients and c) higher risk of virus infection in individuals with comorbidities associated with OC. OC and COVID-19 patients report chronic inflammation and hyper-coagulation which could be the result of a dysregulated RAAS system [114, 165, 174]. Further, the levels of gonadotropin and androgen are also higher in both disease conditions $[21,46,110]$. Whether RAAS and hormonal regulation predispose OC patients to COVID19 is the subject of future investigation.

\section{Physiological Role of Renin-Angiotensin-Aldosterone System (RAAS)}

RAAS is an essential regulatory mechanism for blood pressure and homeostasis. It is inclusive of two functionally opposing axes- ACE/Ang II/AT1 (proliferative/ vasoconstrictor) and ACE2/Ang-(1-7)/MAS1 (anti-proliferative/ vasodilator) [114]. The precursor protein angiotensinogen secreted from the liver forms angiotensin I (Ang I) when cleaved by renin. ACE then converts Ang I to Ang II. Alternatively, ACE2 can act on Ang I to form angiotensin 1-9 [Ang-(1-9)]. Furthermore, ACE can convert Ang-(1-9) to Ang-(1-7) while Ang II can be converted to Ang-(1-7) by ACE2 [195]. The successive action of neutral endopeptidase (NEP) and prolyl endopeptidase (PEP) on Ang I also lead to the formation of Ang-(1-7) [6]. Binding of Ang II to ATR1 trigger downstream signaling pathways which involves a) phosphorylation of p65 subunit of the transcription factor, NF- $\kappa B$, leading to the release of cytokines such as IL- $1 \beta$, IL-6, TNF- $\alpha$ and IL-10 [82, $114,170], \mathrm{b})$ activation of mitogen-activated protein kinase (MAPK) pathway to release IL-1, TNF- $\alpha$, IL-10 and IL-12 [7, 114, 125], and c) tans-signaling of IL-6/ soluble interleukin 6 receptor (IL-6/sIL-6R) complex that results in activation of STAT3 via glycoprotein (gp130) [31, 114]. Thus, activation of the ACE/Ang II/ AT1R axis induces a continuous cascade of inflammatory responses [114]. To overcome the activity of ACE/ Ang II/AT1R axis, the ACE2/MasR axis of the RAAS system is initiated when Ang II is converted to Ang-(17) by ACE2. Antagonistic to Ang II, Ang-(1-7) is a vasodilatory peptide with anti-thrombotic, antiproliferative, and anti-inflammatory activities. Binding of Ang-(1-7) to MasR receptor suppresses NF- $\mathrm{kB}$, p38MAPK, and expression of inflammatory proteins thus preventing the damage [177, 209, 216]. Additionally, Ang-(1-7) modulates the extracellular signal-regulated kinase $1 / 2(E R K 1 / 2)$ pathway by phosphorylation of ERK1/2 in the $\beta$-arrestin dependent mechanism. ERK1/ 2 is involved in the regulation of anti-inflammatory cytokine IL-10. IL-10 enhances the differentiation of T helper (Th) cells to Th2 type, which in turn produces anti-inflammatory cytokines such as IL-4, IL-5, IL-9, and IL-13 [48, 114, 175].

Two other G-protein coupled receptors which are involved are bradykinin B1 receptor (BKB1R) and bradykinin B2 receptor (BKB2R). While the vasodilator bradykinin (BK) is the ligand for $\mathrm{BKB} 2 \mathrm{R}$, the agonist of bradykinin (des-Arg9)-BK/ DABK is the ligand for BKB1R [116, 117]. Although in normal physiological conditions, expression of BKB1R is negligible, its expression is upregulated by cytokines such as TNF- $\alpha$ and IL$1 \beta$. BKB1R activation enhances the neutrophil infiltration and increases the level of IL-1B and MCP-1 [16, 38, $122,150]$. The ligand of BKB1R, DABK, which is also an inflammatory factor, is normally cleaved by ACE2 to deactivate the DABK and prevent the release of inflammatory cytokines $[114,186]$. 
Although earlier identified as involved in the maintenance of blood pressure and homeostasis, the importance of RAAS system in the ovaries of mammal inclusive of human have been demonstrated. The ovary is the major source for the precursor of renin, prorenin [147]. Ang-(17) is considered important for steroidogenesis, and the release of LH-stimulated progesterone was prevented by inhibition of ACE and PEP [149]. In the active ovary, the mRNA expression of MAS, ACE2, and ACE was observed in the granulosa cell. Additionally, the theca cells of secondary follicles were positive for Ang-(1-7) and MAS in the ovulatory stage while, it was negative in pre-ovulatory follicles. The staining of stromal cells of follicles showed the presence of MAS receptor, ACE2, and Ang-(1-7); but the Ang-(1-7) concentration was significantly lower in comparison to Ang II. This may be due to the short halflife of Ang-(1-7) in the plasma [40, 154].

The alteration in the expression level of various RAAS components is suggested to be regulated by the gonadotropin [40]. The patients treated with recombinant FSH or human chorionic gonadotropin (hCG) reported increased plasma Ang-(1-7). Ang II receptors are expressed in theca and granulosa cells. The increased level of Ang II has been observed after the LH surge [2]. The in vivo treatment with gonadotropin-releasing hormone $(\mathrm{GnRH})$ reportedly increased the expression of both Ang II and Ang-(1-7). Tonellotto dos Santos et al. [178] demonstrated that continuous expression of PEP, NEP, ACE2, and MAS in granulosa and theca cells after treatment GnRH; however, Ang-(1-7) level was elevated at 24hours post-treatment. This elevation in Ang-(1-7) was suggested as a result of cleaved Ang II rather than the conversion of Ang I to the intermediate peptide [178].

\section{Effect of dysregulated RAAS on SARS-CoV-2 and OC Cytokines overproduction}

Respiratory transmission is the primary route of infection for SARS-CoV-2 [56]. The entry of SARS-CoV-2 into the host cell is mediated by binding of its surface spike glycoprotein ( $\mathrm{S}$ protein) to the angiotensinconverting enzyme 2 (ACE2) receptor of the host cell, however; ACE2 is minimally expressed in human lung cells [56]. Interrogating microarray datasets of previous infections of Middle-East respiratory syndrome coronavirus (MERS-CoV) and SARS-CoV indicated increased mRNA expression of ACE2. Similar observations have been made during the ongoing pandemic where ACE2 expression at transcript level was 3.6 fold higher in the nasopharyngeal swab specimens from COVID-19 positive patients [215]. ACE2 upregulation is mediated by an innate immune signaling pathway activated by TLR and RNA sensor (retinoic acid-inducible gene I /melanoma differentiation-associated gene 5- mitochondrial antiviral signaling protein axis or RIG-I/MDA-5-MAVS signaling cascade), which ultimately induce the production of inflammatory cytokines [215]. Other studies have suggested an alternative mechanism for inflammatory cytokine production where cyclic GMP-AMP synthasestimulator of interferon genes (cGAS-STING) mediate the activation of NF- $\mathrm{kB}$ signaling cascade [141]. The promoter of ACE2 contain a binding site for various transcription factors, including STAT5, STAT1, STAT3, c-Jun, interferon regulator factor (IRF) 1 , IRF8, and IRF2 [215]. Human bronchial epithelial cells treated with interferon-beta (IFN- $\beta$ ) showed a significant increase in ACE2 mRNA expression. ACE2 promoter activity was also enhanced by inflammatory cytokines such as interferon-alpha (IFN- $\alpha), \quad$ IFN- $\beta$, interferon-gamma (IFN- $\gamma)$, TNF- $\alpha$, IL-6, IL- $1 \alpha$, or IL-1 $\beta$ [215]. Expression of the membrane ACE2 receptor is a critical factor for the initiation and spread of infection by SARS-CoV and SARS-CoV-2 $[185,190]$. The release of interferon and cytokines to the surrounding cells by virus-infected cells might enhance the expression of ACE2 in nearby uninfected cells, thereby rendering them susceptible to SARS-CoV-2 infection.

Although mRNA expression of ACE2 increases upon SARS-CoV infection, it is downregulated at the protein level implying a possible truncation or secretion upon infection [57]. The absence of membrane bound ACE2 may inhibit the formation of Ang-(1-7), thus disturbing the ACE2/Ang1-7/MAS-axis function [54, 100]. Whether this phenomenon is recapitulated in SARS$\mathrm{CoV}-2$ infections as observed in SARS-CoV infections will remains to be determined. COVID-19 patients are characterized by excessive cytokine production, pulmonary shutdown, and thromboembolism events. Imbalance in the ACE/ACE2 pathway results in hypertension, atherosclerosis, thrombosis, heart or kidney failure, and severe respiratory distress, the comorbidities observed among COVID-19 positive patients [52, 163]. This suggests that dysregulation in the function of angiotensinconverting enzyme-1/angiotensin II/ angiotensin II type 1 receptor (ACE1/Ang-II/AT1) axis and angiotensinconverting enzyme-2/ Angiotensin (1-7)/ MAS1 protooncogene (ACE2/Ang1-7/ MAS) axis play a critical role in the pathogenesis of COVID-19.

The disorderly release of cytokines, also known as cytokine storm, leads to a hyper-inflammatory state and have been previously associated with the severity of SARS-CoV and MERS-CoV infections as well as now with the SARSCoV-2 $[89,171,198]$. The downregulation of ACE2 upon infection is considered the underpinning pathology behind the disease's severity as recombinant ACE2 protects mice from acute lung failure [78]. Treatment with ACE2 neutralized the virus by competitive binding. Thus, the cellular ACE2 remains available for maintenance of the counter-regulatory function. 
The binding of SARS-CoV-2 to the host cell receptor triggers receptor-mediated endocytosis of the complex, leading to downregulation of ACE2 [54]. This downregulation of ACE2 potentially results in a continuous supply of Ang II in the presence of unaltered ACE while decreasing the levels of Ang-(1-7). Elevated levels of Ang II in the serum was reported in COVID-19 subjects, and the level correlates with the severity of the infection $[105,106]$. Additionally, increased differentiation of $\mathrm{CD} 4^{+}$lymphocytes to Th-17 was demonstrated with an increase in Th-17 response in MERS-CoV, SARS-CoV, and SARS-CoV-2 patients $[105,106,114]$. Inhibition of ACE in COVID-19 patients with hypertension reported reduced disease severity with downregulation of IL-6 and higher $\mathrm{T}$ cell numbers, suggesting the exaggerated activation of Ang-II/AT1R axis may contribute towards the uncontrolled cytokine response leading to ALD [114, 127]. Similarly, in the presence of inflammatory cytokines, expression of BKB1R is enhanced while, the absence of ACE2 result in activated DABK which, when bound to its receptor BKB1R, initiates the inflammatory signaling producing more cytokines [114, 150, 186]. Thus, downregulation of the ACE2 after SARS-CoV-2 infection deregulates the RAAS, attenuates Mas receptor (ACE2/MasR axis), and activates [des-Arg9]-bradykinin (ACE2/bradykinin B1R/DABK axis) and these are responsible for the overproduction of cytokines causing the cytokine storm [114].

Another pathway that contributes toward a cytokine storm is the activation of complement cascade upon viral infection. Previous in vivo mice study for acute respiratory viral infection (MERS-CoV and SARS-CoV), reported hyperactivation of complement component (C) $5 \mathrm{a}$ and C5b in serum and lung respectively. The mice model deficient for C3 were mildly infected by SARS$\mathrm{CoV}$ and had less circulatory chemokines and cytokines, suggesting viral infection activates the complement cascade that induces inflammatory process $[61,87]$. Investigation of the lung of deceased COVID-19 patient reported deposition of $\mathrm{C} 3, \mathrm{C} 3 \mathrm{a}$, as well as complement complex C5b-9 in the lung and elevation of C5a in the circulation [113]. C5a is the potent mediator of inflammation that can increase secretion of IL- 6 , TNF- $\alpha$, and IL-1 from TLR-2, TLR-4, and/or TLR-9 stimulated macrophages $[43,114]$. The complement cascade's activation is suggested to be mediated by auto-activation of the key serine protease in the lectin pathway upon binding of the viral nucleocapsid $(\mathrm{N})$ to mannose-binding lectin (MLB), the intermediate of MLB complementation pathway [50]

In the context of ovary, although normal follicle's stromal cells showed intense staining for Ang-(1-7), MAS and ACE2 receptor, their expression in the postmenopausal women was less intense. ACE activity is comparatively higher in the ovary of postmenopausal than premenopausal women $[40,154]$. In normal and ovarian tumors, AT1 is localized in the cytoplasm but its expression was evident only in the $\mathrm{OC}$ correlating with the stage of cancer [79]. The overexpression of angiogenic VEGF and increased micro-vessel density, along with AT1 overexpression in OC patients with poor outcomes, suggested the role of dysregulated RAAS in OC development [174]. A recent study by Zhang et al. [211] revealed the triggering of classical ATR1 pathway (through AKT and ERK signaling) by Ang II and also by the transactivation of epidermal growth factor receptor (EGFR) pathway. Further ATR1 activation upregulates stearoyl-CoA desaturase-1 (SCD1) which promotes progression and metastasis as SCD1 increases lipid desaturation, thus reducing the stress to the endoplasmic reticulum [211].

\section{Coagulation}

A higher level of mean platelet volume (MPV) and observation of thromboembolism among the COVID-19 patient [210] suggest a dysregulated coagulation pathway. $\mathrm{Du}$ et al. [41] suggested the downregulation of ACE2 expression as well as a dysregulated immune response because of cytokine storm can lead to vascular injury and activation of the platelets. Similarly, increased production of other factors of coagulation pathways such as tissue factor, plasminogen, and others lead to a hypercoagulable state resulting in the thromboembolic events, as reported in a severe case of COVID-19 [41].

Microarray based gene expression profiling of peritoneal structure in individuals with EOC showed altered expression of inflammation and coagulation associated genes [188]. The observation of thromboembolism among cancer patients could be due to the activation of the coagulation cascade [156]. The coagulation pathway proteins have also been identified to contribute to tumor cell proliferation, invasion angiogenesis, and metastasis [193].

\section{Influence of OC microenvironment to SARS-CoV-2 infection}

Compared to females, males are considered more susceptible to the SARS-CoV-2 infection and one of the factors suspected for the susceptibility is the differences in the sex hormone [52]. However, with an increase in age, this difference becomes less evident. Although the FSH and LH levels are altered over various phases of the menstrual cycle, the concentration remains higher among the elderly women. The highest concentration is among the women who had attained menopause as they lack negative feedback mechanisms by ovarian steroids $[19,21]$. LH induces the synthesis of androgens while FSH stimulates estrogen synthesis from the androgen [53]. However, in 
the absence of pre-ovulatory follicles during menopause, estrogen cannot be produced; thereby, an increase in the androgen level can be expected. Fogle et al. (2007) [46] has demonstrated a significant contribution of the postmenopausal ovary in the production of testosterone and androstenedione [46]. Estrogen is considered as an immune stimulant when present at a basal level and as an immune suppressive hormone at a higher level [52, 173]. Menopause women are reported with higher TNF- $\alpha$, IL- 6 , and CRP levels [168]. Thus, the low level of estrogen can be considered as one of the contributors to create an inflammatory microenvironment among postmenopausal women. Cannon et al. [21] reported enhanced secretion of cytokines IL-1 $\beta$, IL- 6 , TNF- $\alpha$ and upon in vitro treatment of monocytes with exogenous FSH [21]. LH depletes the antioxidant, ascorbic acid, thus increasing the free radical levels and inflammatory mediators [140]. Since ACE/ACE2 increases with the age; the RAAS pathway imbalance can lead to excessive cytokine and chemokine production thus contributing to a higher inflammatory response observed among menopausal women $[145,206]$. Several proteases are reported to activate coronaviruses in vitro, including trypsin-like serine proteases such as the transmembrane serine protease (TMPRSS)2, TMPR SS11A, TMPRSS11D, FURIN and cathepsin L $[11,67$, 71, 131]. FURIN and TMPRSS2 are reported to be candidate genes relevant for SARS-CoV-2 entry into the host cells [72]. Expression of TMPRSS2, which is involved in priming of S-protein during SARS-CoV-2 infection is stimulated by several pro-inflammatory conditions as well as androgens [56]. It is therefore conceivable that individuals with $\mathrm{OC}$ and comorbidities could be more susceptible to SARS-CoV-2 infection. In silico expression analysis of ACE2, TMPRSS2, and FURIN genes in normal ovarian and fallopian tube tissue and the constituent cells were carried out using Genotype-Tissue Expression (GTEx) [22] and Genevestigator [75] respectively. Further, the expression levels were compared to that in lung tissue. A consistently high expression of FURIN across the tissues and constituent cells was observed whereas, ACE2 expression levels across the tissues and cells were similar in both lung and ovary. TMPRSS2 showed high expression levels in the lungs and medium to low expression in ovary and fallopian tissue (Fig. 1a, b). The expression levels of these three genes when analyzed in different subtypes of ovarian carcinomas using Genevestigator showed medium to
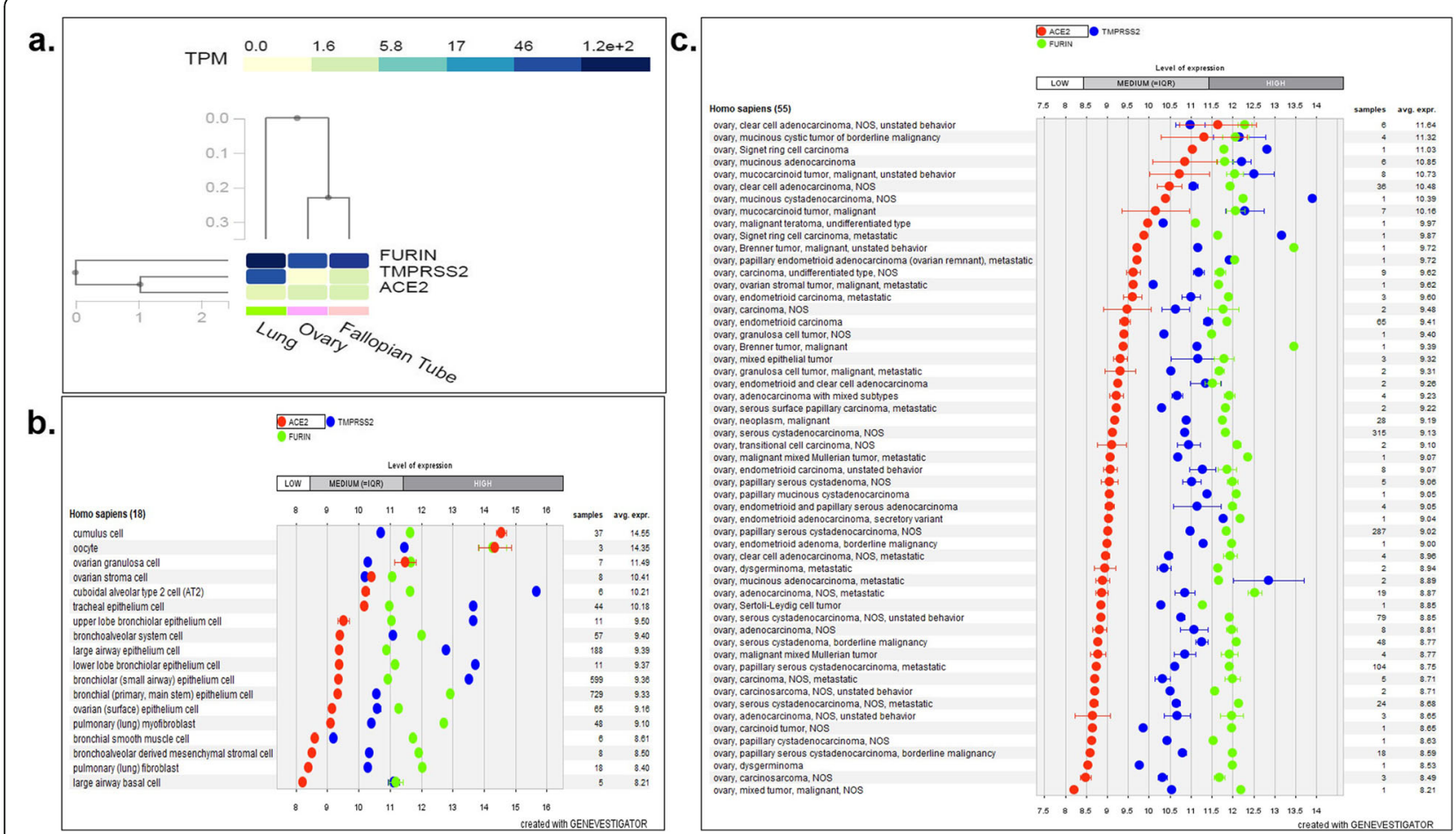

Fig. 1 In silico gene expression profiles in various tissues. Expression of ACE2, TMPRSS2, and FURIN genes in (a) normal ovarian, lung, and other female reproductive organ tissues (data accessed via GTEx portal), (b) various normal cells of lung and ovary and (c) in ovarian and fallopian neoplasms (created using Genevestigator). Analysis revealed medium to high expression of the genes in the malignant ovarian tissues suggesting a potential route of SARS-CoV-2 entry 
high expression in the malignant tissue (Fig. 1c). This suggests a greater susceptibility of viral entry in ovarian tumors.

\section{Influence of SARS-CoV-2 infection on OC}

The circulatory inflammatory marker specifically IL-2, IL-4, IL-6, IL-12, and IL-13 are associated with the risk of EOC [30]. Cytokine storm (hyper-production of inflammatory cytokines) during SARS infection could increase the risk of OC. While interaction of the proinflammatory cytokine IL-6 with its membrane-bound receptor activates classical IL- 6 signaling and contributes to its role in inflammation, its interaction with sIL-6R mediates the function of pro-inflammatory cytokines via trans-signaling pathway [153]. Increased expression of sIL-6R and IL-6 are reported in malignant ascites of OC patients. The IL-6/sIL-6R complex has been demonstrated to activate ERK pathway on endothelial cells and increases endothelial hyper-permeability via Src kinase activation and phosphorylation of vascular endothelialspecific cadherin (VE-cadherin). Thus, IL-6 transsignaling by sIL-6R contributes toward endothelial survival, migration, and integrity resulting in the progression of OC [107]. In patients infected with Influenza A virus (IAV) infection, there is an elevation of soluble IL$6 \mathrm{R}$, an outcome that increases the expression of its ligand, IL- 6 and inflammatory cytokine IL-32. This suggests that sIL-6R is a key molecule involved in inflammatory response to viral infection [191]. Similarly, concomitant expression of sIL-6R during SARS-CoV-2 infection could potentially create a microenvironment in the ovary or distant organs to initiate the cancer progression.

The serum profiling of both ovarian cancer individuals as well as SARS-CoV-2 patients reported an elevated level of prolactin (PRL) $[99,110]$. PRL binding activates prolactin receptor (PRLR), a type-1 family cytokine receptor, which then stimulates a signaling cascade through the activation of STAT5 $[4,68]$ resulting in increased inflammation and proliferation [181]. PRLR cascade can activate MAPK pathway [3], which is reported to be inhibited by the ACE2/Ang-(1-7)/Mas axis [128]. Competitive inhibition of ACE2 receptor through viral binding can downregulate the ACE2/Ang-(1-7)/Mas axis, thereby stimulating MAPK activity (Fig. 2). These suggest a possible role of PRL in potentiating severe outcomes of OC in COVID-19 subjects.

\section{Increased severity of SARS-CoV-2 infection in ovarian cancer patients}

Upon infection, the innate immune signaling is activated which can be mediated by RIG-1/MDA5-MAVS axis [136]. RIG1 like receptors (RLRs) are pathogen recognition receptors that are activated upon recognition of the pathogen-associated molecular patterns (PAMPs) and these interact with MAVS to form a complex. This complex activates TANK binding kinase 1 (TBK1) and inhibitor of nuclear factor kappa-B kinase subunit epsilon

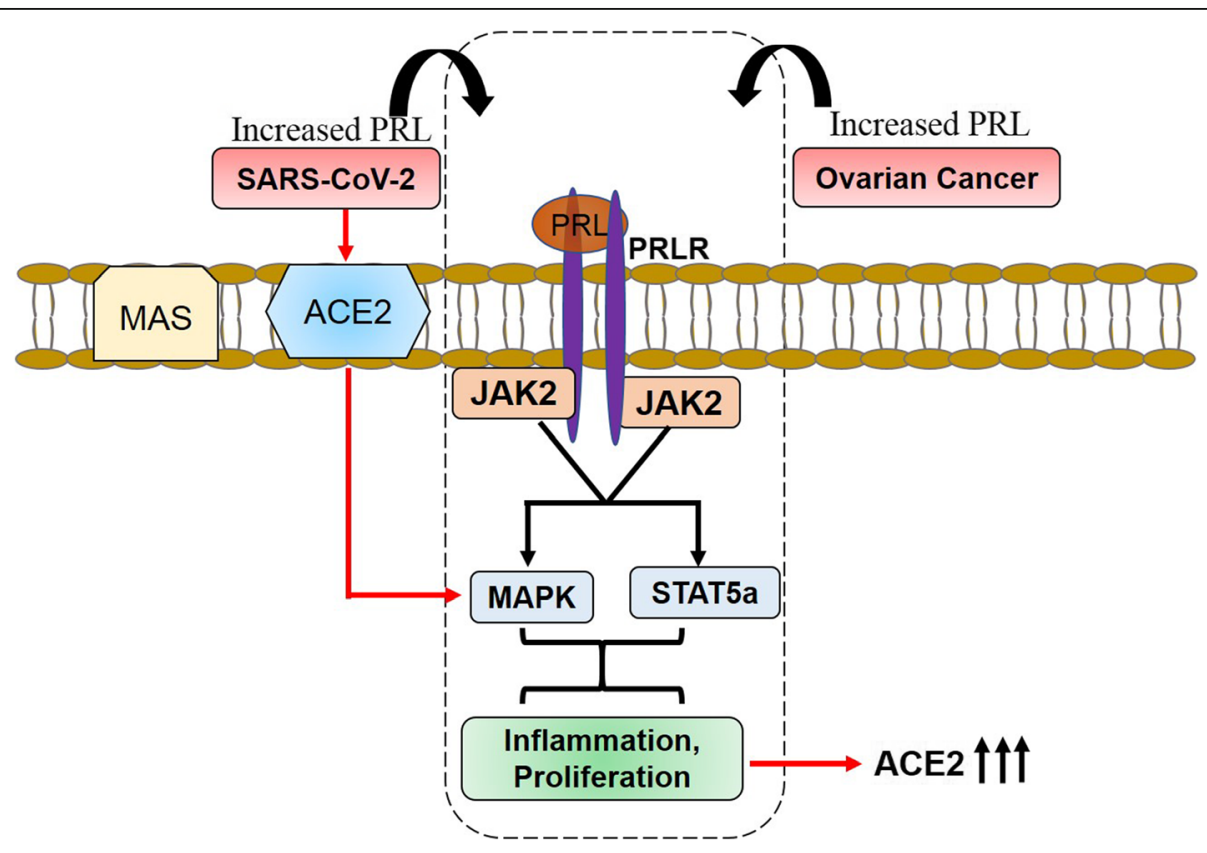

Fig. 2 The influence of serum prolactin levels in both COVID-19 and OC affected subjects. Competitive inhibition of ACE2/Ang-(1-7)/Mas axis due to viral binding can inhibit ACE2 mediated suppression of MAPK. Hence, SARS-CoV-2 binding to ACE2 receptor may increase MAPK activation which can be further potentiated by PRL binding to PRLR thereby substantially increasing the MAPK activity in the cells leading to increase proliferation and inflammation, hence assisting in severe outcomes of ovarian cancer 
(IKKع) and phosphorylates transcription factor IRF3 [136]. Alternatively, cGAS-STING pathway exists in which the cyclic dinucleotides species (CDNs) such as cdi-AMP or cyclic GMP-AMP (cGAMP) are produced by cGAS upon association with cytosolic double-stranded DNA or double-stranded RNA [29]. The association of activated STING with TBK1 at the Golgi complex is important to activate NF- $\mathrm{kB}$ and IRF3 to produce type I interferon and inflammatory cytokines [142]. However, the non-canonical pathway in the cGAS-STING pathway also exists which activates NF- $\mathrm{kB}$ in TBK1 independent manner [10, 152].

Type 1 interferon levels are minimal in patients infected with SARS-CoV-2. Additionally, non-structural protein (NSP) 13 and NSP15 interact with TBK1 or its adaptor protein [59] although TBK1 phosphorylation is inhibited [13,59]. These findings suggest inhibition of RIG-1/MDA5 axis by blocking the activation of TBK1 upon viral infection. However, the cytokine levels and transcriptome profiling from the cell lines infected with SARS-CoV-2, showed cGAS-STING mediated activation of NF-kB and inflammatory response [141]. Activation of cGAS occurs upon sensing the released DNA from mitochondria or nuclei due to cellular stress rather than direct sensing of dsRNA of SARS-CoV-2 [73]. The dsRNA is formed during replication and in case of SARS-CoV2, replication occurs within the double membrane vesicle formed during endocytosis [92, 93]. Neufeldt et al., [141] suggested the translocation of activated STING from ER to Golgi is inhibited by SARS-CoV-2 infection, thereby, inhibiting its interaction with TBK1 and its downstream pathway. However, activated STING stimulates NF- $\mathrm{kB}$ by a non-canonical pathway to produce inflammatory cytokines [141].

In various $\mathrm{OC}$ cell lines and tissue, impaired expression of cGAS and STING have been reported which is mediated by methylation of the promoter region [37]. Although the RIG-1/MDA5 axis is intact, the ability of SARS-CoV-2 to block this axis could suggest a potential increase in severity upon infection of the OC patients with SARS-CoV-2 because of the suppression of innate immune signaling pathway [37]. Besides, cGAS-STING activated signaling may also lead to inflammationinduced carcinogenesis and hence may worsen the disease.

\section{COVID-19 mRNA vaccine, inflammation and effects on ovarian cancer subjects}

Several curative strategies such as combination treatment with systemic corticosteroids (dexamethasone), oxygen therapy, convalescent plasma from recovered COVID-19 patients, drugs such as tocilizumab, hydroxychloroquine, and remdesivir were deployed against SARS-CoV-2 as no definitive vaccine and vaccination strategy were available [12]. However, their impact on individuals with $\mathrm{OC}$ or any other cancer types remains to be established. We highlight briefly below the potential vaccine effects on effector cells and molecules associated with inflammation and OC.

During viral replication after host cell entry, an infected cell undergoes programmed cell death leading to release of damage associated molecular patterns (DAMPs). These molecules are recognized by macrophages, nearby epithelial and endothelial cells and are triggered to release inflammatory chemokines and cytokines. This initiates a cascade of inflammatory reactions where macrophages, monocytes, and $\mathrm{T}$ cells are attracted to the site of infection [176]. Naive CD4+ T cells are presented with viral antigens by antigen presenting dendritic cells and are further activated to release IL-2, TNF- $\alpha$, and IFN- $\gamma$. CD4+ T cell promotes differentiation of cytotoxic CD8+T cells via the secretion of cytokines. Upon activation of these $\mathrm{T}$ cells through antigen recognition, the cells undergo clonal expansion [148] and eliminate the virus infected cells through several well established mechanisms which induce apoptosis or release of cytokines such as TNF- $\alpha$ and IFN- $\gamma[90$, 180]. Specific CD4+T cells elicit potent B cell responses that result in antibody affinity maturation [84]. SARS$\mathrm{CoV}-2$ specific $\mathrm{CD} 4+\mathrm{T}$ cells and $\mathrm{CD} 8+\mathrm{T}$ cells have been identified in the recovered COVID-19 patients and these are shown to recognize peptides of viral spike, nucleoprotein, and matrix as well as other viral proteins [32, 63].

Based on above immune response strategies, development of vaccine against COVID-19 had been initiated. Two mRNA-based SARS-CoV-2 candidate vaccines, mRNA-1273 [187] and BNT162b2 [80] were the first to be granted emergency authorization in Europe and USA. Both are composed of nucleoside modified mRNA encoding full length prefusion SARS-CoV-2 spike protein encapsulated in lipid nanoparticles [182]. The data provided after Phase $1 / 2$ study for BTN162b2 reported robust expansion of spike protein specific $\mathrm{CD} 4+$ and $\mathrm{CD} 8+\mathrm{T}$ cell responses. Cytokines such as IFN- $\gamma$ and IL2 were produced and CD8 $+\mathrm{T}$ cell responses against multiple regions of spike protein were molecularly identified [159]. Previously, vaccination with human papillomavirus (HPV) L1 virus-like particles (VLP) have demonstrated to induce dendritic cells and potent $\mathrm{B}$ cells, hence induction of cytokines such as IL-2, IL-4, IL5, IL-6, IL-10, IL-13, TNF- $\alpha$, IFN- $\gamma$, IP-10, and MIP-1 [51]. Similarly, influenza specific CD4+ and CD8+ T cell response as well as release of cytokines such as IL-5, IL9, IL-10, IL-13, IL-17A, IL17F, IL-21, and IFN- $\gamma$ was reported upon administration of virus like particle based vaccine [169]. However, extensive data on the efficacy and safety of the COVID-19 mRNA vaccine on an 
individual with comorbid conditions and cancer remains to be reported.

The severe cases of COVID-19 are often presented with cytokine storm and lymphopenia [76, 203]. The severely ill and deceased COVID-19 subjects show expressively lower lymphocyte (CD8+ and CD4+ T cells) levels than the survivors $[39,158]$; however, with the higher neutrophil counts compared to lymphocytes [103, 189]. In addition, the CD4+ and CD8+ $\mathrm{T}$ cells from critically ill COVID-19 patients highly express inhibitory receptor such as T-cell immunoglobulin mucin-3 (Tim-3) and Programmed cell death protein 1 (PD-1) [109, 212, 214]. The increased level of TNF- $\alpha$, IL- 6 , and IL-10 is inversely correlated with the decreased $\mathrm{T}$ cell population $[85,135]$ and IL-2, IL-7, IL-15, and IL-21 were reported to upregulate PD-1 expression on T cells [91]. Expression of these markers indicate exhaustion of $\mathrm{T}$ cells with decreased cytokine production and cytotoxic function [109]. The inefficiency of immune cells to eliminate viral infected cells might hyper-activate other immune mediators such as macrophage, neutrophils, monocytes, dendritic cells among others to release excessive cytokines to compensate for the low functional lymphocytes that might ultimately represent cytokine storm [45].

Infiltration of tumor infiltrating lymphocytes (TILs) are observed in different types of cancer including OC and has been significantly correlated with patient outcome (reviewed by [139]). The anti-tumor response or the tumor promoting response of these infiltrating immune cells is critically determined by the tumor microenvironment that constitute cytokines, chemokines, antigens and costimulatory molecules [49]. These immune cells can recognize specific antigens present on the surface of tumor cell and induce anti-tumor response [192]. However, cancer cells are also capable of creating an immunosuppressive microenvironment via the release of inhibitory cytokines, expression of inhibitory molecules and infiltration of immunosuppressive cells such as M2 macrophage and regulatory $\mathrm{T}$ cells ( $\mathrm{T}$ Regs) [194] to down regulate anti-tumor activity of the lymphocytes. Characterization of lymphocytes in tumor and ascites from advanced stage $\mathrm{OC}$ showed higher proportions of $\mathrm{CD} 4+$ and $\mathrm{CD} 8+\mathrm{T}$ cells expressing exhaustive markers such as PD1 and TIM-3 [151]. Additionally, the cancer patients undergoing treatment are immunocompromised and show lymphopenia. In the absence of the CD4+ and CD8+ T effector lymphocytes, which play a key role in eliciting antiviral responses [126] and dendritic cells, which play a major role in controlling antiviral interferon responses [137], vaccine may be functionally incompetent for a cancer patient [15]. Previous reports show that ovarian cancer patients undergoing chemotherapy cannot generate antibody response to inactivated influenza vaccines [28]. However, the data for efficacy and outcome of SARS-CoV-2 vaccines in ovarian cancer patients is unavailable. OC which is associated with several comorbidities such as metabolic diabetes mellitus and obesity have altered cytokine profile in patients resulting in a pro-inflammatory and protumorigenic microenvironment [33]. This can further complicate the immune system response to the vaccines with potential adverse immunogenic as well as cytokine storm reactions with side effects and may pose a major challenge to any vaccination strategy. Thus, further studies to explore potential side effects of SARS-CoV-2 vaccines in ovarian cancer patients as well as to improve our understanding of molecular relationships between cancer and SARS-CoV-2 are necessary.

\section{Conclusion}

In this review, we have attempted to delineate and summarize the impact of comorbidities, gene defects, and inflammatory milieu associated with OC and SARS $\mathrm{CoV}-2$ infection. While there is merit for using agonists and antagonists of specific pathways as anti-cancer agents, their use in the clinical therapeutics requires caution. The network of inflammation-related genes modulated in SARS-CoV-2 infection and the underlying comorbid conditions may promote alterations in signaling pathways that could consequently lead to severe inflammation-induced cancer pathogenesis and/or impart undesirable outcomes in OC patients. Defining the immunological landscape of tumors upon SARS CoV-2 infection may facilitate implementation of effective anticancer therapy and disease management.

\section{Abbreviations}

OC: Ovarian cancer; EOC: Epithelial ovarian cancer; GLOBOCAN: Global cancer statistics; COVID-19: Coronavirus disease; SARS-CoV-2: Severe acute

respiratory syndrome coronavirus 2; SARS-CoV: Severe acute respiratory syndrome coronavirus; MERS-CoV: Middle-East respiratory syndrome coronavirus; WHO: World Health Organization; S-protein: Spike glycoprotein; RAAS: Renin-angiotensin-aldosterone system; FSH: Follicle stimulating hormone; LH: Luteinizing hormone; GnRH: Gonadotropin releasing hormone; OCPs: Oral contraceptive pills; HRT: Hormone replacement therapy; TLR: Toll like receptors; HNP1: Human neutrophil peptide; IL: Interleukins; CCL2: CCchemokine ligand 2; M-CSF: Macrophage colony-stimulating factor; TNFa: Tumor necrosis factor a; TRAIL: Tumor necrosis factor (TNF)-related apoptosis inducing ligand; MIF: Macrophage migration inhibitory factor; LIF: Leukemia inhibitory factor; TNFR1: Tumor necrosis factor receptor 1; NFKB: Nuclear factor kappa B; HIF1a: Hypoxia-inducible factor 1-alpha;

STAT: Signal transducer and activator of transcription; CRP: C-reactive protein; ACE2: Angiotensin-converting enzyme 2; RIG-I/MDA-5-MAVS: Retinoic acidinducible gene I /melanoma differentiation-associated gene 5- mitochondrial antiviral signalling protein axis; IRF: Interferon regulator factor; IFN: Interferon; ARDS: Acute respiratory distress syndrome; ALD: Acute lung Damage; TGF$\beta 1$ : Transforming growth factor-beta 1; MCP: Monocyte chemoattractant protein; MAPK: Mitogen-activated protein kinase; ERK: Extracellular signalregulated kinase; BK: Bradykinin; BKB1R: Bradykinin B1 receptor;

BKB2R: Bradykinin B2 receptor; DABK: (des-Arg9)-BK; G-CSF: Granulocytecolony stimulating factor; IP10: Interferon gamma-induced protein 10; SCF: Stem cell factor; HGF: Hepatocyte growth factor; bFGF: basic fibroblast growth factor; GRO-a: Growth-regulated oncogene alpha; MIG: Monokine induced by interferon (IFN)- $\gamma$; CTACK: Cutaneous T cell-attracting chemokine; 
SDF-1a: stromal cell-derived factor 1; MIP: Macrophage inflammatory protein; VEGF: Vascular endothelial growth factor; SCGF: Stem cell growth factor; TMPRSS: Transmembrane serine protease; PRL: Prolactin; RLRs: RIG1 like receptors; CGAS-STING: cyclic GMP-AMP synthase-stimulator of interferon genes; TBK1: TANK binding kinase 1; IKKE: Inhibitor of nuclear factor kappa-B kinase subunit epsilon; CGAMP: cyclic GMP-AMP; NSP: Non-structural protein; ACE1/Ang-II/AT1: Angiotensin-converting enzyme-1/angiotensin II/ angiotensin II type 1 receptor; ACE2/Ang1-7/ MAS: Angiotensin-converting enzyme-2/ Angiotensin (1-7)/ MAS1 proto-oncogene; NEP: Neutral endopeptidase; PEP: Prolyl endopeptidase; sIL-6R: Soluble interleukin 6 receptor; gp130: glycoprotein; Th: T helper; MPV: Mean platelet volume; C5b: Complement component 5b; MLB: Mannose-binding lectin; hCG: human chorionic gonadotrophin; SCD1: stearoyl-CoA desaturase-1; GTEx: Genotype-Tissue Expression; N: Nucleocapsid; VE-cadherin: Vascular endothelial-specific cadherin; IAV: Influenza A virus; PRLR: Prolactin receptor; PAMPs: Pathogen-associated molecular patterns; PIGF: Placental growth factor; PDGF-BB: Platelet-derived growth factor-BB; RANTES: Regulated on activation, normal T cell expressed and secreted; DAMPs: Damage associated molecular patterns; MHC I: Major histocompatibility class I; HPV: Human papillomavirus; VLP: Virus-like particles; PD-1: Programmed cell death protein 1; Tim-3: T-cell immunoglobulin mucin-3; TILs: Tumor infiltrating lymphocytes; T Regs: Regulatory T cells

\section{Acknowledgements}

Authors thank Manipal Academy of Higher Education, Manipal and TIFACCORE in Pharmacogenomics for the support. We thank Indian Council of Medical Research for the Junior Research Fellowships (ICMR-JRF) to Satyajit Dey Pereira.

\section{Authors' contributions}

Conceptualization, Kapaettu Satyamoorthy and Benjamin K Tsang; Data curation, Sima Chaudhari, Satyajit Dey Pereira and Ritam Naha; Formal analysis, Sima Chaudhari, Satyajit Dey Pereira and Ritam Naha; Supervision, Kapaettu Satyamoorthy, Benjamin K Tsang, Meshach Asare-Warehene and Shama Prasada Kabekkodu; Writing original draft, Sima Chaudhari, Satyajit Dey Pereira and Ritam Naha; Writing- review and editing, Kapaettu Satyamoorthy, Shama Prasada Kabekkodu, Benjamin K Tsang and Meshach AsareWarehene. All authors read and approved the final manuscript.

\section{Funding}

Not applicable

\section{Availability of data and materials}

Not applicable

\section{Ethics approval and consent to participate}

Not applicable

\section{Consent for publication}

Not applicable

\section{Competing interests}

The authors declare that they have no competing interests

\section{Author details}

'Department of Cell and Molecular Biology, Manipal School of Life Science, Manipal Academy of Higher Education, Manipal, Karnataka 576104, India. ${ }^{2}$ Chronic Disease Program, Ottawa Hospital Research Institute and Department of Obstetrics \& Gynecology and Cellular and Molecular Medicine, University of Ottawa, Ottawa, Ontario K1N 6N5, Canada.

Received: 21 November 2020 Accepted: 9 February 2021

Published online: 25 February 2021

\section{References}

1. Abdulkhaleq LA, Assi MA, Abdullah R, Zamri-Saad M, Taufiq-Yap YH, Hezmee MN. The crucial roles of inflammatory mediators in inflammation: a review. Vet World. 2018;1 1:627-35. https://doi.org/10.14202/vetworld.2018.627-635.

2. Acosta TJ, Ozawa T, Kobayashi S, Hayashi K, Ohtani M, Kraetzl WD, Sato K, Schams D, Miyamoto A. Periovulatory changes in the local release of vasoactive peptides, prostaglandin F2a, and steroid hormones from bovine mature follicles in vivo. Biol Reprod. 2000;63:1253-61. https://doi.org/10.1 095/biolreprod63.5.1253.

3. Aksamitiene E, Achanta S, Kolch W, Kholodenko BN, Hoek JB, Kiyatkin A. Prolactin-stimulated activation of ERK1/2 mitogen-activated protein kinases is controlled by PI3-kinase/Rac/PAK signaling pathway in breast cancer cells. Cell Signal. 2011;23:1794-805. https://doi.org/10.1016/j.cellsig.2011.06.014.

4. Ali S, Ali S. Prolactin receptor regulates stat5 tyrosine phosphorylation and nuclear translocation by two separate pathways. J Biol Chem. 1998;273: 7709-16. https://doi.org/10.1074/jbc.273.13.7709.

5. Alisson-Silva F, Kawanishi K, Varki A. Human risk of diseases associated with red meat intake: analysis of current theories and proposed role for metabolic incorporation of a non-human sialic acid. Mol Aspects Med. 2016; 51:16-30. https://doi.org/10.1016/.j.mam.2016.07.002.

6. Ardaillou R, Chansel D. Synthesis and effects of active fragments of angiotensin II. Kidney Int. 1997;52:1458-68. https://doi.org/10.1038/ki.1997.4 76.

7. Arthur JS, Ley SC. Mitogen-activated protein kinases in innate immunity. Nat Rev Immunol. 2013;13:679-92. https://doi.org/10.1038/nri3495.

8. Asare-Werehene M, Communal L, Carmona E, Le T, Provencher D, MesMasson AM, Tsang BK. Pre-operative circulating plasma Gelsolin predicts residual disease and detects early stage ovarian cancer. Sci Rep. 2019;9:1-9. https://doi.org/10.1038/s41598-019-50436-1.

9. Auersperg N, Wong AS, Choi KC, Kang SK, Leung PC. Ovarian surface epithelium: biology, endocrinology, and pathology. Endocr Rev. 2001;22: 255-88. https://doi.org/10.1210/edrv.22.2.0422.

10. Bakhoum SF, Ngo B, Laughney AM, Cavallo JA, Murphy CJ, Ly P, Shah P, Sriram RK, Watkins TB, Taunk NK, Duran M. Chromosomal instability drives metastasis through a cytosolic DNA response. Nature. 2018;553:467-72. https://doi.org/10.1038/nature25432.

11. Bestle D, Heindl MR, Limburg H, Pilgram O, Moulton H, Stein DA, Hardes K, Eickmann M, Dolnik O, Rohde C, Klenk HD. TMPRSS2 and furin are both essential for proteolytic activation of SARS-CoV-2 in human airway cells. Life Sci Alliance. 2020;3:e202000786-10.26508/sa.202000786.

12. Bhagat S, Yadav N, Shah J, Dave H, Swaraj S, Tripathi S, Singh S. Novel corona virus (COVID-19) pandemic: current status and possible strategies for detection and treatment of the disease. Expert Rev Anti Infect Ther. 2020:124. https://doi.org/10.1080/14787210.2021.1835469.

13. Blanco-Melo D, Nilsson-Payant BE, Liu WC, Uhl S, Hoagland D, Møller R, Jordan TX, Oishi K, Panis M, Sachs D, Wang TT. Imbalanced host response to SARS-CoV-2 drives development of COVID-19. Cell. 2020;181:1036-1045.e9. https://doi.org/10.1016/j.cell.2020.04.026.

14. Booth A, Magnuson A, Fouts J, Foster M. Adipose tissue, obesity and adipokines: role in cancer promotion. Horm Mol Biol Clin Investig. 2015;21: 57-74. https://doi.org/10.1515/hmbci-2014-0037.

15. Borchardt RA, Torres HA. Challenges in managing hepatitis $\mathrm{C}$ virus infection in cancer patients. World J Gastroenterol. 2014;20:2771-6. https://doi.org/1 0.3748/wjg.v20.111.2771.

16. Bouthillier J, Deblois D, Marceau F. Studies on the induction of pharmacological responses to des-Arg9-bradykinin in vitro and in vivo. $\mathrm{Br} J$ Pharmacol. 1987;92:257-64. https://doi.org/10.1111/j.1476-5381.1987.tb11319.x.

17. Bray F, Ferlay J, Soerjomataram I, Siegel RL, Torre LA, Jemal A. Global cancer statistics 2018: GLOBOCAN estimates of incidence and mortality worldwide for 36 cancers in 185 countries. CA: Cancer J Clin. 2018;68:394-424. https:// doi.org/10.3322/caac.21492.

18. Brodlie M, McKean MC, Johnson GE, Anderson AE, Hilkens CM, Fisher AJ Corris PA, Lordan JL, Ward C. Raised interleukin-17 is immunolocalised to neutrophils in cystic fibrosis lung disease. Eur Respir J. 2011;37:1378-85. https://doi.org/10.1183/09031936.00067110.

19. Burger HG, Dudley EC, Hopper JL, Groome N, Guthrie JR, Green A, Dennerstein L. Prospectively measured levels of serum follicle-stimulating hormone, estradiol, and the dimeric inhibins during the menopausal transition in a population-based cohort of women. J Clin Endocrinol Metab. 1999;84:4025-30. https://doi.org/10.1210/jcem.84.11.6158.

20. Calderon-Margalit R, Friedlander Y, Yanetz R, Deutsch L, Perrin MC, Kleinhaus K, Tiram E, Harlap S, Paltiel O. Preeclampsia and subsequent risk of cancer: update from the Jerusalem Perinatal Study. Am J Obstet Gynecol. 2009;200: 63-e1-5. https://doi.org/10.1016/j.ajog.2008.06.057.

21. Cannon JG, Cortez-Cooper M, Meaders E, Stallings J, Haddow S, Kraj B, Sloan G, Mulloy A. Follicle-stimulating hormone, interleukin-1, and bone density in adult women. Am J Physiol Regul Integr Comp Physiol. 2010;298:R790-8. https://doi.org/10.1152/ajpregu.00728.2009. 
22. Carithers $\amalg$, Ardlie K, Barcus M, Branton PA, Britton A, Buia SA, Compton CC, DeLuca DS, Peter-Demchok J, Gelfand ET, Guan P. A novel approach to high-quality postmortem tissue procurement: the GTEx project. Biopreserv Biobank. 2015;13:311-9. https://doi.org/10.1089/bio.2015.0032.

23. Cascella M, Bimonte S, Barbieri A, Del Vecchio V, Caliendo D, Schiavone V, Fusco R, Granata V, Arra C, Cuomo A. Dissecting the mechanisms and molecules underlying the potential carcinogenicity of red and processed meat in colorectal cancer (CRC): an overview on the current state of knowledge. Infect Agent Cancer. 2018;13:3. https://doi.org/10.1186/s13027018-0174-9.

24. Ceccarelli M, Berretta M, Rullo EV, Nunnari G, Cacopardo B. Editorialdifferences and similarities between severe acute respiratory syndrome (SARS)-CoronaVirus (CoV) and SARS-CoV-2. Would a rose by another name smell as sweet? Eur Rev Med Pharmacol Sci. 2020;24:2781-3. https://doi. org/10.26355/eurrev_202003 20551.

25. Chan JK, Urban R, Cheung MK, Osann K, Husain A, Teng NN, Kapp DS, Berek JS, Leiserowitz GS. Ovarian cancer in younger vs older women: a population-based analysis. Br J Cancer. 2006;95:1314-20. https://doi.org/10.1 038/sj.bjc.6603457.

26. Cheung CY, Poon LL, Lau AS, Luk W, Lau YL, Shortridge KF, Gordon S, Guan $Y$, Peiris JS. Induction of proinflammatory cytokines in human macrophages by influenza $A(\mathrm{H} 5 \mathrm{~N} 1)$ viruses: a mechanism for the unusual severity of human disease? Lancet. 2002;360:1831-7. https://doi.org/10.1016/s0140-673 6(02)11772-7.

27. Choi JH, Wong AS, Huang HF, Leung PC. Gonadotropins and ovarian cancer. Endocr Rev. 2007;28:440-61. https://doi.org/10.1210/er.2006-0036.

28. Chu CS, Boyer JD, Jawad A, McDonald K, Rogers WT, Luning Prak ET, Sullivan KE. Immunologic consequences of chemotherapy for ovarian cancer: impaired responses to the influenza vaccine. Vaccine. 2013;31:543542. https://doi.org/10.1016/j.vaccine.2013.09.001.

29. Civril F, Deimling T, de Oliveira Mann CC, Ablasser A, Moldt M, Witte G, Hornung V, Hopfner KP. Structural mechanism of cytosolic DNA sensing by cGAS. Nature. 2013;498:332-7. https://doi.org/10.1038/nature12305.

30. Clendenen TV, Lundin E, Zeleniuch-Jacquotte A, Koenig KL, Berrino F, Lukanova A, Lokshin AE, Idahl A, Ohlson N, Hallmans G, Krogh V. Circulating inflammation markers and risk of epithelial ovarian cancer. Cancer Epidemiol Biomarkers Prev. 2011;20:799-810. https://doi.org/10.1158/10559965.EPI-10-1180.

31. Coles B, Fielding CA, Rose-John S, Scheller J, Jones SA, O'Donnell VB. Classic interleukin-6 receptor signaling and interleukin-6 trans-signaling differentially control angiotensin I-dependent hypertension, cardiac signal transducer and activator of transcription-3 activation, and vascular hypertrophy in vivo. Am J Pathol. 2007;171:315-25. https://doi.org/10.2353/a jpath.2007.061078

32. Cox RJ, Brokstad KA. Not just antibodies: B cells and T cells mediate immunity to COVID-19. Nat Rev Immunol. 2020;20:581-2. https://doi.org/1 0.1038/s41577-020-00436-4

33. Craig ER, Londoño Al, Norian LA, Arend RC. Metabolic risk factors and mechanisms of disease in epithelial ovarian cancer: a review. Gynecol Oncol. 2016;143:674-83. https://doi.org/10.1016/j.ygyno.2016.10.005.

34. Cramer DW, Welch WR. Determinants of ovarian cancer risk. II. Inferences regarding pathogenesis. J Natl Cancer Inst. 1983;71:717-21. https://doi.org/1 0.1093/jnci/71.4.717.

35. Crowley-Nowick PA. Basic principles of immunology and genital tract immunity. In: Ness RB, Kuller LH, editors. Health and disease among women. Biological and environmental influences. New York: Oxford University Press; 1998. p. 273-96

36. Crusz SM, Balkwill FR. Inflammation and cancer: advances and new agents. Nat Rev Clin Oncol. 2015;12:584-96. https://doi.org/10.1038/nrclinonc.2015.105.

37. De Queiroz NM, Xia T, Konno H, Barber GN. Ovarian cancer cells commonly exhibit defective STING signaling which affects sensitivity to viral oncolysis. Mol Cancer Res. 2019;17:974-86. https://doi.org/10.1158/1 541-7786.MCR-18-0504.

38. Deblois D, Bouthillier J, Marceau F. Effect of glucocorticoids, monokines and growth factors on the spontaneously developing responses of the rabbit isolated aorta to des-Arg9-bradykinin. Br J Pharmacol. 1988;93:969-677. https://doi.org/10.1111/j.1476-5381.1988.tb11487.X.

39. Diao B, Wang C, Tan Y, Chen X, Liu Y, Ning L, Chen L, Li M, Liu Y, Wang G, Yuan Z. Reduction and functional exhaustion of $T$ cells in patients with coronavirus disease 2019 (COVID-19). Front Immunol. 2020;11:827. https:// doi.org/10.3389/fimmu.2020.00827.
40. Domińska K. Involvement of ACE2/Ang-(1-7)/MAS1 axis in the regulation of ovarian function in mammals. Int J Mol Sci. 2020;21:4572. https://doi.org/1 0.3390/ijms21134572.

41. Du F, Liu B, Zhang S. COVID-19: the role of excessive cytokine release and potential ACE2 down-regulation in promoting hypercoagulable state associated with severe illness. J Thromb Thrombolysis. 2020;16:1-17. https:// doi.org/10.1007/s11239-020-02224-2.

42. Faber MT, Jensen A, Frederiksen K, Glud E, Høgdall E, Høgdall C, Blaakær J, Kjaer SK. Oral contraceptive use and impact of cumulative intake of estrogen and progestin on risk of ovarian cancer. Cancer Causes Control. 2013;24:2197-206. https://doi.org/10.1007/s10552-013-0296-8.

43. Fang C, Zhang X, Miwa T, Song WC. Complement promotes the development of inflammatory T-helper 17 cells through synergistic interaction with Toll-like receptor signaling and interleukin-6 production. Blood. 2009;114:1005-15. https://doi.org/10.1182/blood-2009-01-198283.

44. Fathalla MF. Incessant ovulation - a factor in ovarian neoplasia. Lancet. 1971;2:163. https://doi.org/10.1016/s0140-6736(71)92335-x.

45. Fathi N, Rezaei N. Lymphopenia in COVID-19: therapeutic opportunities. Cell Biol Int. 2020;44:1792-7. https://doi.org/10.1002/cbin.11403.

46. Fogle RH, Stanczyk FZ, Zhang X, Paulson RJ. Ovarian androgen production in postmenopausal women. J Clin Endocrinol Metab. 2007;92:3040-3. https://doi.org/10.1210/jc.2007-0581.

47. Funston $\mathrm{G}$, Van Melle M, Baun ML, Jensen H, Helsper C, Emery J, Crosbie EJ, Thompson M, Hamilton W, Walter FM. Variation in the initial assessment and investigation for ovarian cancer in symptomatic women: a systematic review of international guidelines. BMC Cancer. 2019;19:1028. https://doi. org/10.1186/s12885-019-6211-2.

48. Gallagher PE, Tallant EA. Inhibition of human lung cancer cell growth by angiotensin-(1-7). Carcinogenesis. 2004;25:2045-52. https://doi.org/10.1093/ carcin/bgh236.

49. Galli F, Aguilera JV, Palermo B, Markovic SN, Nisticò P, Signore A. Relevance of immune cell and tumor microenvironment imaging in the new era of immunotherapy. J Exp Clin Cancer Res. 2020;39:89. https://doi.org/10.1186/ s13046-020-01586-y.

50. Gao T, Hu M, Zhang X, Li H, Zhu L, Liu H, Dong Q, Zhang Z, Wang Z, Hu Y, Fu Y. Highly pathogenic coronavirus $N$ protein aggravates lung injury by MASP-2-mediated complement over-activation. MedRxiv. 2020. https://doi. org/10.1101/2020.03.29.20041962

51. García-Piñeres A, Hildesheim A, Dodd L, Kemp TJ, Williams M, Harro C, Lowy DR, Schiller JT, Pinto LA. Cytokine and chemokine profiles following vaccination with human papillomavirus type $16 \mathrm{~L} 1$ virus-like particles. Clin Vaccine Immunol. 2007;14:984-9. https://doi.org/10.1128/CVI.00090-07.

52. Gemmati D, Bramanti B, Serino ML, Secchiero P, Zauli G, Tisato V. COVID-19 and individual genetic susceptibility/receptivity: role of ACE1/ACE2 genes, immunity, inflammation and coagulation. Might the double X-chromosome in females be protective against SARS-CoV-2 compared to the single $X$ chromosome in males? Int J Mol Sci. 2020;21:3474-96. https://doi.org/10.33 90/ijms21103474.

53. Gervásio CG, Bernuci MP, Silva-de-Sá MF, Rosa-e-Silva AC. The role of androgen hormones in early follicular development. ISRN Obstet Gynecol. 2014;2014:818010. https://doi.org/10.1155/2014/818010.

54. Gheblawi M, Wang K, Viveiros A, Nguyen Q, Zhong JC, Turner AJ, Raizada MK, Grant MB, Oudit GY. Angiotensin-converting enzyme 2: SARS-CoV-2 receptor and regulator of the renin-angiotensin system: celebrating the 20th anniversary of the discovery of ACE2. Circ Res. 2020;126:1456-74. https://doi.org/10.1161/CIRCRESAHA.120.317015.

55. Gibson SJ, Fleming GF, Temkin SM, Chase DM. The application and outcome of standard of care treatment in elderly women with ovarian cancer: a literature review over the last 10 years. Front Oncol. 2016;6:63. https://doi.org/10.3389/fonc.2016.00063.

56. Gkogkou E, Barnasas G, Vougas K, Trougakos IP. Expression profiling metaanalysis of ACE2 and TMPRSS2, the putative anti-inflammatory receptor and priming protease of SARS-CoV-2 in human cells, and identification of putative modulators. Redox Biol. 2020;36:101615. https://doi.org/10.1016/j. redox.2020.101615.

57. Glowacka I, Bertram S, Herzog P, Pfefferle S, Steffen I, Muench MO, Simmons G, Hofmann H, Kuri T, Weber F, Eichler J. Differential downregulation of ACE2 by the spike proteins of severe acute respiratory syndrome coronavirus and human coronavirus NL63. J Virol. 2010;84:1198-205. https://doi.org/10.1128/JVI.01248-09.

58. Gomez-Roman N, Sahasrabudhe NM, McGregor F, Chalmers AJ, Cassidy J, Plumb J. Hypoxia-inducible factor 1 alpha is required for the tumourigenic 
and aggressive phenotype associated with Rab25 expression in ovarian cancer. Oncotarget. 2016;7:22650-64. https://doi.org/10.18632/oncotarget. 7998.

59. Gordon DE, Jang GM, Bouhaddou M, Xu J, Obernier K, White KM, O'Meara MJ, Rezelj W, Guo JZ, Swaney DL, Tummino TA. A SARS-CoV-2 protein interaction map reveals targets for drug repurposing. Nature. 2020;583:45968. https://doi.org/10.1038/s41586-020-2286-9.

60. Gorelik E, Landsittel DP, Marrangoni AM, Modugno F, Velikokhatnaya L, Winans MT, Bigbee WL, Herberman RB, Lokshin AE. Multiplexed immunobead-based cytokine profiling for early detection of ovarian cancer. Cancer Epidemiol Biomark Prev. 2005;14:981-7. https://doi.org/10.1158/1 055-9965.EPI-04-0404.

61. Gralinski LE, Sheahan TP, Morrison TE, Menachery VD, Jensen K, Leist SR, Whitmore A, Heise MT, Baric RS. Complement activation contributes to severe acute respiratory syndrome coronavirus pathogenesis. mBio. 2018;9: e01753-18. https://doi.org/10.1128/mBio.01753-18.

62. Green A, Purdie D, Bain C, Siskind V, Russell P, Quinn M, Ward B. Tubal sterilisation, hysterectomy and decreased risk of ovarian cancer. Int J Cancer. 1997;71:948-51. https://doi.org/10.1002/(sici)1097-0215(19970611)71:6<948::a id-ijc6>3.0.c0;2-y.

63. Grifoni A, Weiskopf D, Ramirez SI, Mateus J, Dan JM, Moderbacher CR, Rawlings SA, Sutherland A, Premkumar L, Jadi RS, Marrama D. Targets of T cell responses to SARS-CoV-2 coronavirus in humans with COVID-19 disease and unexposed individuals. Cell. 2020;181:1489-1501.e15. https://doi.org/1 0.1016/j.cell.2020.05.015.

64. Hagimoto N, Kuwano K, Inoshima I, Yoshimi M, Nakamura N, Fujita M Maeyama T, Hara N. TGF- $\beta 1$ as an enhancer of Fas-mediated apoptosis of lung epithelial cells. J Immunol. 2002;168:6470-8. https://doi.org/10.4049/ jimmunol.168.12.6470.

65. Harrington BS, Annunziata CM. NF-KB signaling in ovarian cancer. Cancers (Basel). 2019;11:1182. https://doi.org/10.3390/cancers11081182.

66. He L, Ding Y, Zhang Q, Che X, He Y, Shen H, Wang H, Li Z, Zhao L, Geng J, Deng $Y$. Expression of elevated levels of pro-inflammatory cytokines in SARS-CoV-infected ACE2+ cells in SARS patients: relation to the acute lung injury and pathogenesis of SARS. J Pathol. 2006;210:288-97. https://doi.org/1 0.1002/path.2067.

67. Heald-Sargent T, Gallagher T. Ready, set, fuse! The coronavirus spike protein and acquisition of fusion competence. Viruses. 2012;4:557-80. https://doi. org/10.3390/v4040557.

68. Hennighausen L, Robinson GW, Wagner K-U, Liu X. Prolactin signaling in mammary gland development. J Biol Chem. 1997;272:7567-9. https://doi. org/10.1074/jbc.272.12.7567.

69. Herlaar E, Brown Z. p38 MAPK signalling cascades in inflammatory disease. Mol Med Today. 1999:5:439-47. https://doi.org/10.1016/s1357-4310(99)01 544-0.

70. Hodge DR, Hurt EM, Farrar WL. The role of IL-6 and STAT3 in inflammation and cancer. Eur J Cancer. 2005;41:2502-12. https://doi.org/10.1016/j.ejca.2 005.08.016.

71. Hoffmann M, Hofmann-Winkler H, Pöhlmann S. Priming time: how cellular proteases arm coronavirus spike proteins. In: Activation of viruses by host proteases. Cham: Springer; 2018. p. 71-98.

72. Hoffmann M, Kleine-Weber H, Schroeder S, Krüger N, Herrler T, Erichsen S, Schiergens TS, Herrler G, Wu NH, Nitsche A, Müller MA. SARS-CoV-2 cell entry depends on ACE2 and TMPRSS2 and is blocked by a clinically proven protease inhibitor. Cell. 2020;181:271-80. https://doi.org/10.1016/j.cell.2020. 02.052.

73. Hopfner KP, Hornung V. Molecular mechanisms and cellular functions of cGAS-STING signalling. Nat Rev Mol Cell Biol. 2020;21:501-21. https://doi. org/10.1038/s41580-020-0244-X.

74. House CD, Jordan E, Hernandez L, Ozaki M, James JM, Kim M, Kruhlak MJ Batchelor E, Elloumi F, Cam MC, Annunziata CM. NFKB promotes ovarian tumorigenesis via classical pathways that support proliferative cancer cells and alternative pathways that support ALDH+ cancer stem-like cells. Cancer Res. 2017:77:6927-40. https://doi.org/10.1158/0008-5472.CAN-17-0366.

75. Hruz T, Laule O, Szabo G, Wessendorp F, Bleuler S, Oertle L, Widmayer P, Gruissem W, Zimmermann P. Genevestigator v3: a reference expression database for the meta-analysis of transcriptomes. Adv Bioinformatics. 2008; 2008:420747. https://doi.org/10.1155/2008/420747.

76. Huang C, Wang Y, Li X, Ren L, Zhao J, Hu Y, Zhang L, Fan G, Xu J, Gu X, Cheng Z, Yu T, Xia J, Wei Y, Wu W, Xie X, Yin W, Li H, Liu M, Xiao Y, Gao H, Guo L, Xie J, Wang G, Jiang R, Gao Z, Jin Q, Wang J, Cao B. Clinical features of patients infected with 2019 novel coronavirus in Wuhan, China. Lancet. 2020:395:497-506. https://doi.org/10.1016/S0140-6736(20)30183-5.

77. Hudson JD, Shoaibi MA, Maestro R, Carnero A, Hannon GJ, Beach DH. A proinflammatory cytokine inhibits p53 tumor suppressor activity. J Exp Med. 1999;190:1375-82. https://doi.org/10.1084/jem.190.10.1375.

78. Imai Y, Kuba K, Rao S, Huan Y, Guo F, Guan B, Yang P, Sarao R, Wada T, Leong-Poi $\mathrm{H}$, Crackower MA. Angiotensin-converting enzyme 2 protects from severe acute lung failure. Nature. 2005;436:112-6. https://doi.org/10.1 038/nature03712.

79. Ino K, Shibata K, Kajiyama H, Yamamoto E, Nagasaka T, Nawa A, Nomura S, Kikkawa F. Angiotensin II type 1 receptor expression in ovarian cancer and its correlation with tumour angiogenesis and patient survival. $\mathrm{Br} J$ Cancer. 2006;94:552-60. https://doi.org/10.1038/sj.bjc.6602961.

80. Jackson LA, Anderson EJ, Rouphael NG, Roberts PC, Makhene M, Coler RN, McCullough MP, Chappell JD, Denison MR, Stevens LJ, Pruijssers AJ, McDermott A, Flach B, Doria-Rose NA, Corbett KS, Morabito KM, O'Dell S, Schmidt SD, Swanson PA 2nd, Padilla M, Mascola JR, Neuzil KM, Bennett H, Sun W, Peters E, Makowski M, Albert J, Cross K, Buchanan W, Pikaart-Tautges R, Ledgerwood JE, Graham BS, Beigel JH, mRNA-1273 Study Group. An mRNA vaccine against SARS-CoV-2 - preliminary report. N Engl J Med. 2020; 383:1920-31. https://doi.org/10.1056/NEJMoa2022483.

81. Jaiswal M, LaRusso NF, Burgart LJ, Gores GJ. Inflammatory cytokines induce DNA damage and inhibit DNA repair in cholangiocarcinoma cells by a nitric oxide-dependent mechanism. Cancer Res. 2000;60:184-90.

82. Jamaluddin M, Meng T, Sun J, Boldogh I, Han Y, Brasier AR. Angiotensin II induces nuclear factor (NF)-kB1 isoforms to bind the angiotensinogen gene acute-phase response element: a stimulus-specific pathway for NF-kB activation. Mol Endocrinol. 2000;14:99-113. https://doi.org/10.1210/ mend.14.1.0400

83. Jammal MP, Martins-Filho A, Silveira TP, Murta EF, Nomelini RS. Cytokines and prognostic factors in epithelial ovarian cancer. Clin Med Insights: Oncol. 2016;10:71-6. https://doi.org/10.4137/CMO.S38333.

84. Janeway Jr CA, Travers P, Walport M, Shlomchik MJ. B-cell activation by armed helper T cells. InImmunobiology: the immune system in health and disease. 5th edn. 2001. Garland Science.

85. Jeffery LE, Burke F, Mura M, Zheng Y, Qureshi OS, Hewison M, Walker LS, Lammas DA, Raza K, Sansom DM. 1,25-Dihydroxyvitamin D3 and IL-2 combine to inhibit $T$ cell production of inflammatory cytokines and promote development of regulatory T cells expressing CTLA-4 and FoxP3. J Immunol. 2009;183:5458-67. https://doi.org/10.4049/jimmunol.0803217.

86. Jia D, Nagaoka Y, Katsumata M, Orsulic S. Inflammation is a key contributor to ovarian cancer cell seeding. Sci Rep. 2018;8:12394. https://doi.org/10.103 8/s41598-018-30261-8.

87. Jiang Y, Zhao G, Song N, Li P, Chen Y, Guo Y, Li J, Du L, Jiang S, Guo R, Sun S. Blockade of the C5a-C5aR axis alleviates lung damage in hDPP4transgenic mice infected with MERS-CoV. Emerg Microbes Infect. 2018;7:77. https://doi.org/10.1038/s41426-018-0063-8.

88. Kazerouni N, Greene MH, Lacey JV Jr, Mink PJ, Schairer C. Family history of breast cancer as a risk factor for ovarian cancer in a prospective study. Cancer. 2006;107:1075-83. https://doi.org/10.1002/cncr.22082.

89. Kim ES, Choe PG, Park WB, Oh HS, Kim EJ, Nam EY, Na SH, Kim M, Song KH, Bang JH, Park SW. Clinical progression and cytokine profiles of Middle East respiratory syndrome coronavirus infection. J Korean Med Sci. 2016:31:171725. https://doi.org/10.3346/jkms.2016.31.11.1717

90. Kim TS, Shin EC. The activation of bystander CD8+ T cells and their roles in viral infection. Exp Mol Med. 2019;51(12):1-9. https://doi.org/10.1038/s122 76-019-0316-1.

91. Kinter AL, Godbout EJ, McNally JP, Sereti I, Roby GA, O'Shea MA, Fauci AS. The common gamma-chain cytokines IL-2, IL-7, IL-15, and IL-21 induce the expression of programmed death-1 and its ligands. J Immunol. 2008;181: 6738-46. https://doi.org/10.4049/jimmunol.181.10.6738.

92. Klein S, Cortese M, Winter SL, Wachsmuth-Melm M, Neufeldt CJ, Cerikan B, Stanifer ML, Boulant S, Bartenschlager R, Chlanda P. SARS-CoV-2 structure and replication characterized by in situ cryo-electron tomography. BioRxiv. 2020. https://doi.org/10.1101/2020.06.23.167064.

93. Knoops K, Kikkert M, Van Den Worm SH, Zevenhoven-Dobbe JC, Van Der Meer Y, Koster AJ, Mommaas AM, Snijder EJ. SARS-coronavirus replication is supported by a reticulovesicular network of modified endoplasmic reticulum. PLoS Biol. 2008;6:e226. https://doi.org/10.1371/journal.pbio.0060226.

94. Kuper H, Titus-Ernstoff L, Harlow BL, Cramer DW. Population based study of coffee, alcohol and tobacco use and risk of ovarian cancer. Int J Cancer. 
2000;88:313-8. https://doi.org/10.1002/1097-0215(20001015)88:2<313:aidijc26>3.0.co;2-5.

95. Kurman RJ, Shih IM. The origin and pathogenesis of epithelial ovarian cancer-a proposed unifying theory. Am J Surg Pathol. 2010;34:433-43. https://doi.org/10.1097/PAS.0b013e3181cf3d79.

96. Lee LY, Cazier JB, Starkey T, Briggs SE, Arnold R, Bisht V, Booth S, Campton NA, Cheng WW, Collins G, Curley HM. COVID-19 prevalence and mortality in patients with cancer and the effect of primary tumour subtype and patient demographics: a prospective cohort study. Lancet Oncol. 2020b;21:1309-16. https://doi.org/10.1016/S1470-2045(20)30442-3.

97. Lee LY, Cazier JB, Starkey T, Turnbull CD, Team UC, Kerr R, Middleton G. COVID-19 mortality in patients with cancer on chemotherapy or other anticancer treatments: a prospective cohort study. Lancet. 2020a;395:191926. https://doi.org/10.1016/S0140-6736(20)31173-9.

98. Lee M, Rhee I. Cytokine signaling in tumor progression. Immune Netw. 2017;17:214-27. https://doi.org/10.4110/in.2017.17.4.214.

99. Levina W, Nolen B, Su Y, Godwin AK, Fishman D, Liu J, Mor G, Maxwell LG, Herberman RB, Szczepanski MJ, Szajnik ME. Biological significance of prolactin in gynecologic cancers. Cancer Res. 2009;69:5226-33. https://doi. org/10.1158/0008-5472.CAN-08-4652.

100. Li W, Moore MJ, Vasilieva N, Sui J, Wong SK, Berne MA, Somasundaran M, Sullivan JL, Luzuriaga K, Greenough TC, Choe H. Angiotensin-converting enzyme 2 is a functional receptor for the SARS coronavirus. Nature. 2003; 426:450-4. https://doi.org/10.1038/nature02145.

101. Li X, Xu S, Yu M, Wang K, Tao Y, Zhou Y, Shi J, Zhou M, Wu B, Yang Z, Zhang C, Yue J, Zhang Z, Renz H, Liu X, Xie J, Xie M, Zhao J. Risk factors for severity and mortality in adult COVID-19 inpatients in Wuhan. J Allergy Clin Immunol. 2020;146:110-8. https://doi.org/10.1016/j.jaci.2020.04.006.

102. Liang W, Guan W, Chen R, Wang W, Li J, Xu K, Li C, Ai Q, Lu W, Liang H, Li S. Cancer patients in SARS-CoV-2 infection: a nationwide analysis in China. Lancet Oncol. 2020;21:335-7. https://doi.org/10.1016/S1470-2045(20)30096-6.

103. Liao M, Liu Y, Yuan J, Wen Y, Xu G, Zhao J, Cheng L, Li J, Wang X, Wang F, Liu L, Amit I, Zhang S, Zhang Z. Single-cell landscape of bronchoalveolar immune cells in patients with COVID-19. Nat Med. 2020;26:842-4. https:// doi.org/10.1038/s41591-020-0901-9.

104. Lin HW, Tu YY, Lin SY, Su WJ, Lin WL, Lin WZ, Wu SC, Lai YL. Risk of ovarian cancer in women with pelvic inflammatory disease: a population-based study. Lancet Oncol. 2011;12:900-4. https://doi.org/10.1016/S1470-2045(11)70165-6.

105. Liu J, Li S, Liu J, Liang B, Wang X, Wang H, Li W, Tong Q, Yi J, Zhao L, Xiong L, Guo C, Tian J, Luo J, Yao J, Pang R, Shen H, Peng C, Liu T, Zhang Q, Wu J, Xu L, Lu S, Wang B, Weng Z, Han C, Zhu H, Zhou R, Zhou H, Chen X, Ye P, Zhu B, Wang L, Zhou W, He S, He Y, Jie S, Wei P, Zhang J, Lu Y, Wang W, Zhang L, Li L, Zhou F, Wang J, Dittmer U, Lu M, Hu Y, Yang D, Zheng X. Longitudinal characteristics of lymphocyte responses and cytokine profiles in the peripheral blood of SARS-CoV-2 infected patients. EBioMedicine. 2020a;55:102763. https://doi.org/10.1016/j.ebiom.2020.102763.

106. Liu N, Hong Y, Chen RG, Zhu HM. High rate of increased level of plasma Angiotensin II and its gender difference in COVID-19: an analysis of 55 hospitalized patients with COVID-19 in a single hospital, WuHan, China. medRxiv. 2020b. https://doi.org/10.1101/2020.04.27.20080432.

107. Lo CW, Chen MW, Hsiao M, Wang S, Chen CA, Hsiao SM, Chang JS, Lai TC, Rose-John S, Kuo ML, Wei LH. IL-6 trans-signaling in formation and progression of malignant ascites in ovarian cancer. Cancer Res. 2011;71:42434. https://doi.org/10.1158/0008-5472.CAN-10-1496.

108. Lu KH, Daniels M. Endometrial and ovarian cancer in women with Lynch syndrome: update in screening and prevention. Fam Cancer. 2013;12:273-7. https://doi.org/10.1007/s1 0689-013-9664-5.

109. Luo XH, Zhu Y, Mao J, Du RC. T cell immunobiology and cytokine storm of COVID-19. Scand J Immunol. 2020:e12989. https://doi.org/10.1111/sji.12989.

110. Ma L, Xie W, Li D, Shi L, Mao Y, Xiong Y, Zhang Y, Zhang M. Effect of SARSCoV-2 infection upon male gonadal function: A single center-based study. MedRxiv. 2020. https://doi.org/10.1101/2020.03.21.20037267.

111. Maddur MS, Miossec P, Kaveri SV, Bayry J. Th17 cells: biology, pathogenesis of autoimmune and inflammatory diseases, and therapeutic strategies. Am J Pathol. 2012;181:8-18. https://doi.org/10.1016/j.ajpath.2012.03.044.

112. Madigan M, Karhu E. The role of plant-based nutrition in cancer prevention. J Unexplored Med Data. 2018;3. https://doi.org/10.20517/2572-8180.2018.05.

113. Magro C, Mulvey JJ, Berlin D, Nuovo G, Salvatore S, Harp J, Baxter-Stoltzfus A, Laurence J. Complement associated microvascular injury and thrombosis in the pathogenesis of severe COVID-19 infection: a report of five cases. Transl Res. 2020;220:1-13. https://doi.org/10.1016/j.trsl.2020.04.007.
114. Mahmudpour M, Roozbeh J, Keshavarz M, Farrokhi S, Nabipour I. COVID-19 cytokine storm: The anger of inflammation. Cytokine. 2020;133:155151. https://doi.org/10.1016/j.cyto.2020.155151.

115. Mandel M, Harari G, Gurevich M, Achiron A. Cytokine prediction of mortality in COVID19 patients. Cytokine. 2020;134:155190. https://doi.org/10.1016/j. cyto.2020.155190.

116. Manning DC, Snyder SH. Bradykinin receptors localized by quantitative autoradiography in kidney, ureter, and bladder. Am J Physiol Renal Physiol. 1989;256:F909-15. https://doi.org/10.1152/ajprenal.1989.256.5.F909.

117. Mantione CR, Rodriguez R. A bradykinin (BK) 1 receptor antagonist blocks capsaicin-induced ear inflammation in mice. Br J Pharmacol. 1990;99:516-8. https://doi.org/10.1111/j.1476-5381.1990.tb12960.x.

118. Manzi S, Ramsey-Goldman R. Autoimmune diseases. In: Ness RB, Kuller LH, editors. Health and disease among women. Biological and environmental influences. New York: Oxford University Press; 1998. p. 342-72.

119. Marchbanks PA, Wilson H, Bastos E, Cramer DW, Schildkraut JM, Peterson HB. Cigarette smoking and epithelial ovarian cancer by histologic type. Obstet Gynecol. 2000;95:255-60. https://doi.org/10.1016/s0029-7844 (99)00531-1.

120. Martín-Cameán M, Delgado-Sánchez E, Piñera A, Diestro MD, De Santiago J, Zapardiel I. The role of surgery in advanced epithelial ovarian cancer. Ecancermedicalscience. 2016;10:666. https://doi.org/1 0.3332/ecancer.2016.666.

121. McCann SE, Freudenheim JL, Marshall JR, Graham S. Risk of human ovarian cancer is related to dietary intake of selected nutrients, phytochemicals and food groups. J Nutr. 2003;133:1937-42. https://doi.org/10.1093/jn/133.6.1937.

122. McLean $P G$, Perretti $M$, Ahluwalia A. Inducible expression of the kinin $B 1$ receptor in the endotoxemic heart: mechanisms of des-Arg9bradykinininduced coronary vasodilation. Br J Pharmacol. 1999;128:275-82. https://doi. org/10.1038/sj.bjp.0702743.

123. McNamara C, Abbott SE, Bandera EV, Qin B, Peres LC, Camacho F, Moorman PG, Alberg AJ, Barnholtz-Sloan JS, Bondy M, Cote ML. Tubal ligation and ovarian cancer risk in African American women. Cancer Causes Control. 2017;28:1033-41. https://doi.org/10.1007/s10552-017-0943-6.

124. McNeilly AS. Breastfeeding and the suppression of fertility. Food Nutr Bull. 1996;17:1-6. https://doi.org/10.1177/156482659601700412.

125. Mehta PK, Griendling KK. Angiotensin II cell signaling: physiological and pathological effects in the cardiovascular system. Am J Physiol Cell Physiol. 2007;292:C82-97. https://doi.org/10.1152/ajpcell.00287.2006.

126. Ménétrier-Caux C, Ray-Coquard I, Blay JY, Caux C. Lymphopenia in cancer patients and its effects on response to immunotherapy: an opportunity for combination with cytokines? J Immunother Cancer. 2019;7:85. https://doi. org/10.1186/s40425-019-0549-5

127. Meng J, Xiao G, Zhang J, He X, Ou M, Bi J, Yang R, Di W, Wang Z, Li Z, Gao H. Renin-angiotensin system inhibitors improve the clinical outcomes of COVID-19 patients with hypertension. Emerg Microbes Infect. 2020;9:757-60. https://doi.org/10.1080/22221751.2020.1746200.

128. Meng Y, Yu CH, Li W, Li T, Luo W, Huang S, Wu PS, Cai SX, Li X. Angiotensin-converting enzyme 2/angiotensin-(1-7)/Mas axis protects against lung fibrosis by inhibiting the MAPK/NF-KB pathway. Am J Respir Cell Mol Biol. 2014;50:723-36. https://doi.org/10.1165/rcmb.2012-04510C.

129. Mertens-Walker I, Baxter RC, Marsh DJ. Gonadotropin signalling in epithelial ovarian cancer. Cancer Lett. 2012;324:152-9. https://doi.org/10.1016/..ca nlet.2012.05.017.

130. Mikacenic C, Hansen EE, Radella F, Gharib SA, Stapleton RD, Wurfel MM. IL$17 \mathrm{~A}$ is associated with alveolar inflammation and poor outcomes in acute respiratory distress syndrome. Crit Care Med. 2016;44:496-502. https://doi. org/10.1097/CCM.0000000000001409.

131. Millet JK, Whittaker GR. Host cell proteases: critical determinants of coronavirus tropism and pathogenesis. Virus Res. 2015;202:120-34. https:// doi.org/10.1016/j.virusres.2014.11.021

132. Modugno F, Goughnour SL, Wallack D, Edwards RP, Odunsi K, Kelley JL, Moysich K, Ness RB, Brooks MM. Breastfeeding factors and risk of epithelial ovarian cancer. Gynecol Oncol. 2019;153:116-22. https://doi.org/10.1016/j. ygyno.2019.01.017.

133. Mogensen JB, Kiær SK, Mellemkjær L, Jensen A. Endometriosis and risks for ovarian, endometrial and breast cancers: a nationwide cohort study. Gynecol Oncol. 2016;143:87-92. https://doi.org/10.1016/j.ygyno.2016.07.095.

134. Momenimovahed Z, Tiznobaik A, Taheri S, Salehiniya H. Ovarian cancer in the world: epidemiology and risk factors. Int J Womens Health. 2019;11:28799. https://doi.org/10.2147/IJWH.S197604. 
135. Moon C. Fighting COVID-19 exhausts T cells. Nat Rev Immunol. 2020;20:277. https://doi.org/10.1038/s41577-020-0304-7.

136. Morgan Brisse HL. Comparative structure and function analysis of the RIG-Ilike receptors: RIG-I and MDA5. Front Immunol. 2019;10:1586. https://doi. org/10.3389/fimmu.2019.01586.

137. Musella M, Manic G, De Maria R, Vitale I, Sistigu A. Type---interferons in infection and cancer: unanticipated dynamics with therapeutic implications. Oncoimmunology. 2017;6:e1314424. https://doi.org/10.1080/2162402X.201 7.1314424 .

138. Nakamura M, Obata T, Daikoku T, Fujiwara H. The association and significance of p53 in gynecologic cancers: the potential of targeted therapy. Int J Mol Sci. 2019;20:5482. https://doi.org/10.3390/ijms20215482.

139. Nelson BH. The impact of T-cell immunity on ovarian cancer outcomes. Immunol Rev. 2008;222:101-16. https://doi.org/10.1111/j.1600-065X.2008. 00614.x.

140. Ness RB, Cottreau C. Possible role of ovarian epithelial inflammation in ovarian cancer. J Natl Cancer Inst. 1999;91:1459-67. https://doi.org/10.1093/ jnci/91.17.1459.

141. Neufeldt CJ, Cerikan B, Cortese M, Frankish J, Lee JY, Plociennikowska A, Heigwer F, Joecks S, Burkart SS, Zander DY, Gendarme M. SARS-CoV-2 infection induces a pro-inflammatory cytokine response through cGASSTING and NF-KB. bioRxiv. 2020. https://doi.org/10.1101/2020.07.21.212639.

142. Ni G, Ma Z, Damania B. CGAS and STING: At the intersection of DNA and RNA virus-sensing networks. PLoS Pathog. 2018;14:e1007148. https://doi. org/10.1371/journal.ppat.1007148.

143. Nonnenmacher Y, Hiller K. Biochemistry of proinflammatory macrophage activation. Cell Mol Life Sci. 2018;75:2093-109. https://doi.org/10.1007/s0001 8-018-2784-1.

144. Ose J, Schock H, Tjønneland A, Hansen L, Overvad K, Dossus L, ClavelChapelon F, Baglietto L, Boeing H, Trichopolou A, Benetou V. Inflammatory markers and risk of epithelial ovarian cancer by tumor subtypes: the EPIC cohort. Cancer Epidemiol Biomarkers Prev. 2015;24:951-61. https://doi.org/1 0.1158/1055-9965.EPI-14-1279-T.

145. Pagliaro P, Penna C. ACE/ACE2 ratio: a key also in 2019 coronavirus disease (Covid-19)? Front Med. 2020;7:335. https://doi.org/10.3389/fmed.2020.00335.

146. Pan SY, Ugnat AM, Mao Y, Wen SW, Johnson KC, Canadian Cancer Registries Epidemiology Research Group. A case-control study of diet and the risk of ovarian cancer. Cancer Epidemiol Biomarkers Prev. 2004;13:1521-7.

147. Paul M, Poyan Mehr A, Kreutz R. Physiology of local renin-angiotensin systems. Physiol Rev. 2006;86:747-803. https://doi.org/10.1152/physrev.0003 6.2005.

148. Pennock ND, White JT, Cross EW, Cheney EE, Tamburini BA, Kedl RM. T cell responses: naive to memory and everything in between. Adv Physiol Educ. 2013;37:273-83. https://doi.org/10.1152/advan.00066.2013.

149. Pepperell JR, Nemeth G, Yamada Y, Naftolin F, Merino M. Localized accumulation of angiotensin II and production of angiotensin-(1-7) in rat luteal cells and effects on steroidogenesis. Am J Physiol Endocrinol Metab. 2006;291:E221-33. https://doi.org/10.1152/ajpendo.00205.2005.

150. Qadri F, Bader M. Kinin B1 receptors as a therapeutic target for inflammation. Expert Opin Ther Targets. 2018;22:31-44. https://doi.org/10.1 080/14728222.2018.1409724.

151. Rådestad E, Klynning C, Stikvoort A, Mogensen O, Nava S, Magalhaes I, Uhlin M. Immune profiling and identification of prognostic immune-related risk factors in human ovarian cancer. Oncoimmunology. 2018;8:e1535730. https://doi.org/10.1080/2162402X.2018.1535730.

152. Ranoa DR, Widau RC, Mallon S, Parekh AD, Nicolae CM, Huang X, Bolt MJ, Arina A, Parry R, Kron SJ, Moldovan GL. STING promotes homeostasis via regulation of cell proliferation and chromosomal stability. Cancer Res. 2019; 79:1465-79. https://doi.org/10.1158/0008-5472.CAN-18-1972.

153. Reeh H, Rudolph N, Billing U, Christen H, Streif S, Bullinger E, SchliemannBullinger M, Findeisen R, Schaper F, Huber HJ, Dittrich A. Response to IL-6 trans-and IL- 6 classic signalling is determined by the ratio of the IL- 6 receptor a to gp130 expression: fusing experimental insights and dynamic modelling. Cell Commun Signal. 2019;17:46. https://doi.org/10.1186/s12964-019-0356-0.

154. Reis FM, Bouissou DR, Pereira VM, Camargos AF, dos Reis AM, Santos RA. Angiotensin-(1-7), its receptor Mas, and the angiotensin-converting enzyme type 2 are expressed in the human ovary. Fertil Steril. 2011;95:176-81. https://doi.org/10.1016/j.fertnstert.2010.06.060

155. Risch HA. Hormonal etiology of epithelial ovarian cancer, with a hypothesis concerning the role of androgens and progesterone. Natl Cancer Inst. 1998; 90:1774-86. https://doi.org/10.1093/jnci/90.23.1774.
156. Rodriguez AO, Wun T, Chew H, Zhou H, Harvey D, White RH. Venous thromboembolism in ovarian cancer. Gynecol Oncol. 2007:105:784-90. https://doi.org/10.1016/j.ygyno.2007.02.024.

157. Rossing MA, Cushing-Haugen KL, Wicklund KG, Doherty JA, Weiss NS. Menopausal hormone therapy and risk of epithelial ovarian cancer. Cancer Epidemiol Biomarkers Prev. 2007;16:2548-56. https://doi.org/10.1158/10559965.EPI-07-0550.

158. Ruan Q, Yang K, Wang W, Jiang L, Song J. Clinical predictors of mortality due to COVID-19 based on an analysis of data of 150 patients from Wuhan. China. Intensive Care Med. 2020;46:846-8. https://doi.org/10.1007/s00134-02 0-05991-X.

159. Sahin U, Muik A, Vogler I, Derhovanessian E, Kranz LM, Vormehr M, Quandt J, Bidmon N, Ulges A, Baum A, Pascal K. BNT162b2 induces SARS-CoV-2neutralising antibodies and T cells in humans. medRxiv. 2020. https://doi. org/10.1101/2020.12.09.20245175.

160. Salazar-Martinez E, Lazcano-Ponce EC, Lira-Lira GG, Escudero-De los Rios P, Salmeron-Castro J, Hernandez-Avila M. Reproductive factors of ovarian and endometrial cancer risk in a high fertility population in Mexico. Cancer Res. 1999;59:3658-62.

161. Samartzis EP, Noske A, Dedes KI, Fink D, Imesch P. ARID1A mutations and PI3KJAKT pathway alterations in endometriosis and endometriosisassociated ovarian carcinomas. Int J Mol Sci. 2013;14:18824-49. https://doi. org/10.3390/ijms140918824.

162. Sampson JA. Metastatic or embolic endometriosis, due to the menstrual dissemination of endometrial tissue into the venous circulation. Am J Pathol. 1927:3:93-110.

163. Sanyaolu A, Okorie C, Marinkovic A, Patidar R, Younis K, Desai P, Hosein Z, Padda I, Mangat J, Altaf M. Comorbidity and its impact on patients with COVID-19. SN Compr Clin Med. 2020;25:1-8. https://doi.org/10.1007/s42399020-00363-4.

164. Sato HI, Takimoto T, Tanaka S, Ogura H, Shiraishi K, Tanaka J. Cytopathic effects induced by Epstein-Barr virus replication in epithelial nasopharyngeal carcinoma hybrid cells. J Virol. 1989;63:3555-9 doi: 0022-538X/89/08355505\$02.00/0.

165. Savant SS, Sriramkumar S, O'Hagan HM. The role of inflammation and inflammatory mediators in the development, progression, metastasis, and chemoresistance of epithelial ovarian cancer. Cancers. 2018;1:251. https:// doi.org/10.3390/cancers10080251.

166. Scharte M, Han X, Bertges DJ, Fink MP, Delude RL. Cytokines induce HIF-1 DNA binding and the expression of HIF-1-dependent genes in cultured rat enterocytes. Am J Physiol Gastrointest Liver Physiol. 2003;284:G373-84. https://doi.org/10.1152/ajpgi.00076.2002.

167. Shalapour S, Karin M. Immunity, inflammation, and cancer: an eternal fight between good and evil. J Clin Invest. 2015;125:3347-55. https://doi.org/1 $0.1172 / \mathrm{JCl} 80007$

168. Sites CK, Toth MJ, Cushman M, D L'Hommedieu G, Tchernof A, Tracy RP, Poehlman ET. Menopause-related differences in inflammation markers and their relationship to body fat distribution and insulin-stimulated glucose disposal. Fertil Steril. 2002;77:128-35. https://doi.org/10.1016/s0015-0282(01)02934-x.

169. Skibinski DAG, Jones LA, Zhu YO, Xue LW, Au B, Lee B, Naim ANM, Lee A, Kaliaperumal N, Low JGH, Lee LS, Poidinger M, Saudan P, Bachmann M, Ooi EE, Hanson BJ, Novotny-Diermayr V, Matter A, Fairhurst AM, Hibberd ML, Connolly JE. Induction of human T-cell and cytokine responses following vaccination with a novel influenza vaccine. Sci Rep. 2018;8:18007. https:// doi.org/10.1038/s41598-018-36703-7.

170. Skurk T, van Harmelen V, Hauner H. Angiotensin II stimulates the release of interleukin-6 and interleukin-8 from cultured human adipocytes by activation of NF-KB. Arterioscler Thromb Vasc Biol. 2004;24:1199-203. https:// doi.org/10.1161/01.ATV.0000131266.38312.2e.

171. Song P, Li W, Xie J, Hou Y, You C. Cytokine storm induced by SARS-CoV-2. Clin Chim Acta. 2020;509:280-7. https://doi.org/10.1016/j.cca.2020.06.017.

172. Spezzani V, Piunno A, Iselin HU. Benign COVID-19 in an immunocompromised cancer patient-the case of a married couple. Swiss Med Wkly. 2020;150:w20246. https://doi.org/10.4414/smw.2020.20246.

173. Straub RH. The complex role of estrogens in inflammation. Endocr Rev. 2007;28:521-74. https://doi.org/10.1210/er.2007-0001.

174. Suganuma T, Ino K, Shibata K, Kajiyama H, Nagasaka T, Mizutani S, Kikkawa F. Functional expression of the angiotensin II type1 receptor in human ovarian carcinoma cells and its blockade therapy resulting in suppression of tumor invasion, angiogenesis, and peritoneal dissemination. Clin Cancer Res. 2005;11:2686-94. https://doi.org/10.1158/1078-0432.CCR-04-1946. 
175. Tallant EA, Ferrario CM, Gallagher PE. Angiotensin-(1-7) inhibits growth of cardiac myocytes through activation of the mas receptor. Am J Physiol Heart Circ Physiol. 2005;289:H1560-6. https://doi.org/10.1152/ajpheart. 00941.2004 .

176. Tay MZ, Poh CM, Rénia L, MacAry PA, Ng LF. The trinity of COVID-19: immunity, inflammation and intervention. Nat Rev Immunol. 2020;20:36374. https://doi.org/10.1038/s41577-020-0311-8.

177. Thomas MC, Pickering RJ, Tsorotes D, Koitka A, Sheehy K, Bernardi S, Toffoli B, Nguyen-Huu TP, Head GA, Fu Y, Chin-Dusting J. Genetic Ace2 deficiency accentuates vascular inflammation and atherosclerosis in the ApoE knockout mouse. Circ Res. 2010;107:888-97. https://doi.org/10.1161/ CIRCRESAHA.110.219279.

178. Tonellotto dos Santos J, Ferreira R, Gasperin BG, Siqueira LC, de Oliveira JF, Santos RA, Reis AM, Gonçalves PB. Molecular characterization and regulation of the angiotensin-converting enzyme type 2/Angiotensin-(1-7)/MAS receptor axis during the ovulation process in cattle. J Renin Angiotensin Aldosterone Syst. 2012;13:91-8. https://doi.org/10.1177/1470320311417273.

179. Toss A, Tomasello C, Razzaboni E, Contu G, Grandi G, Cagnacci A, Schilder RJ, Cortesi L. Hereditary ovarian cancer: not only BRCA 1 and 2 genes. Biomed Res Int. 2015;2015:341723. https://doi.org/10.1155/2015/341723.

180. Trapani JA, Smyth MJ. Functional significance of the perforin/granzyme cell death pathway. Nat Rev Immunol. 2002;2:735-47. https://doi.org/10.1038/ nri911.

181. Tripathi A, Sodhi A. Prolactin-induced production of cytokines in macrophages in vitro involves JAK/STAT and JNK MAPK pathways. Int Immunol. 2008;20:327-36. https://doi.org/10.1093/intimm/dxm145.

182. Tumban E. Lead SARS-CoV-2 candidate vaccines: expectations from phase III trials and recommendations post-vaccine approval. Viruses. 2020;13:E54. https://doi.org/10.3390/v13010054.

183. Umakanthan S, Chattu VK, Kalloo S. Global epidemiology, risk factors, and histological types of ovarian cancers in Trinidad. J Family Med Prim Care. 2019;8:1058-64. https://doi.org/10.4103/jfmpc.jfmpc_384_18.

184. Vang R, Shih IM, Kurman RJ. Ovarian low-grade and high-grade serous carcinoma: pathogenesis, clinicopathologic and molecular biologic features, and diagnostic problems. Adv Anat Pathol. 2009;16:267-82. https://doi.org/1 0.1097/PAP.0b013e3181b4fffa.

185. Verdecchia P, Cavallini C, Spanevello A, Angeli F. The pivotal link between ACE2 deficiency and SARS-CoV-2 infection. Eur J Intern Med. 2020;76:14-20. https://doi.org/10.1016/j.ejim.2020.04.037.

186. Vickers C, Hales P, Kaushik V, Dick L, Gavin J, Tang J, Godbout K, Parsons T, Baronas E, Hsieh F, Acton S. Hydrolysis of biological peptides by human angiotensin-converting enzyme-related carboxypeptidase. J Biol Chem. 2002;277:14838-43. https://doi.org/10.1074/jbc.M200581200.

187. Walsh EE, Frenck RW Jr, Falsey AR, Kitchin N, Absalon J, Gurtman A, Lockhart S, Neuzil K, Mulligan MJ, Bailey R, Swanson KA, Li P, Koury K, Kalina W, Cooper D, Fontes-Garfias C, Shi PY, Türeci Ö, Tompkins KR, Lyke KE, Raabe V, Dormitzer PR, Jansen KU, Sahin U, Gruber WC. Safety and immunogenicity of two RNA-based Covid-19 vaccine candidates. N Engl J Med. 2020;383 2439-50. https://doi.org/10.1056/NEJMoa2027906.

188. Wang E, Ngalame $Y$, Panelli MC, Nguyen-Jackson $H$, Deavers M, Mueller $P$, Hu W, Savary CA, Kobayashi R, Freedman RS, Marincola FM. Peritoneal and subperitoneal stroma may facilitate regional spread of ovarian cancer. Clin Cancer Res. 2005a;11:113-22.

189. Wang F, Hou H, Luo Y, Tang G, Wu S, Huang M, Liu W, Zhu Y, Lin Q, Mao L, Fang $M$, Zhang $H$, Sun $Z$. The laboratory tests and host immunity of COVID19 patients with different severity of illness. JCI Insight. 2020;5:e137799. https://doi.org/10.1172/jci.insight.137799.

190. Wang H, Yang P, Liu K, Guo F, Zhang Y, Zhang G, Jiang C. SARS coronavirus entry into host cells through a novel clathrin-and caveolae-independent endocytic pathway. Cell Res. 2008;18:290-301. https://doi.org/10.1038/cr.2 008.15.

191. Wang J, Wang Q, Han T, Li YK, Zhu SL, Ao F, Feng J, Jing MZ, Wang L, Ye $L B$, Zhu $Y$. Soluble interleukin-6 receptor is elevated during influenza $A$ virus infection and mediates the IL-6 and IL-32 inflammatory cytokine burst. Cell Mol Immunol. 2015;12:633-44. https://doi.org/10.1038/cmi.2014.80.

192. Wang W, Zou W, Liu JR. Tumor-infiltrating T cells in epithelial ovarian cancer: predictors of prognosis and biological basis of immunotherapy. Gynecol Oncol. 2018;151:1-3. https://doi.org/10.1016/j.ygyno.2018.09.005.

193. Wang X, Wang E, Kavanagh JJ, Freedman RS. Ovarian cancer, the coagulation pathway, and inflammation. J Transl Med. 2005b;3:25. https:// doi.org/10.1186/1479-5876-3-25.
194. Wefers C, Duiveman-de Boer T, Yigit R, Zusterzeel PLM, van Altena AM, Massuger LFAG, De Vries IJM. Survival of ovarian cancer patients is independent of the presence of DC and T cell subsets in ascites. Front Immunol. 2019;9:3156. https://doi.org/10.3389/fimmu.2018.03156.

195. Weir MR, Dzau VJ. The renin-angiotensin-aldosterone system: a specific target for hypertension management. Am J Hypertens. 1999;12:205S-13S. https://doi.org/10.1016/s0895-7061(99)00103-X.

196. Whittemore AS, Wu ML, Paffenbarger RS, Sarles DL, Kampert JB, Grosser S, Jung DL, Ballon S, Hendrickson M, Mohle-Boetani J. Epithelial ovarian cancer and the ability to conceive. Cancer Res. 1989;49:4047-52.

197. Wira CR, Rodriguez-Garcia M, Patel MV. The role of sex hormones in immune protection of the female reproductive tract. Nat Rev Immunol. 2015;15:217-30. https://doi.org/10.1038/nri3819.

198. Wong CK, Lam CW, Wu AK, Ip WK, Lee NL, Chan IH, Lit LC, Hui DS, Chan $\mathrm{MH}$, Chung SS, Sung JJ. Plasma inflammatory cytokines and chemokines in severe acute respiratory syndrome. Clin Exp Immunol. 2004;136:95-103. https://doi.org/10.1111/j.1365-2249.2004.02415.x.

199. www.covid19.who.int/ n.d.

200. Xu Z, Shi L, Wang Y, Zhang J, Huang L, Zhang C, Liu S, Zhao P, Liu H, Zhu L, Tai Y. Pathological findings of COVID-19 associated with acute respiratory distress syndrome. Lancet Respir Med. 2020a;8:420-2. https://doi.org/10.101 6/S2213-2600(20)30076-X.

201. Xu ZS, Shu T, Kang L, Wu D, Zhou X, Liao BW, Sun XL, Zhou X, Wang YY. Temporal profiling of plasma cytokines, chemokines and growth factors from mild, severe and fatal COVID-19 patients. Signal Transduct Target Ther. 2020b;5:100. https://doi.org/10.1038/s41392-020-0211-1.

202. Yabuno A, Matsushita H, Hamano T, Tan TZ, Shintani D, Fujieda N, Tan DSP, Huang RY, Fujiwara K, Kakimi K, Hasegawa K. Identification of serum cytokine clusters associated with outcomes in ovarian clear cell carcinoma. Sci Rep. 2020;10:18503. https://doi.org/10.1038/s41598-020-75536-1.

203. Yang Y, Shen C, Li J, Yuan J, Yang M, Wang F, Li G, Li Y, Xing L, Peng L, Wei J. Exuberant elevation of IP-10, MCP-3 and IL-1 ra during SARS-CoV-2 infection is associated with disease severity and fatal outcome. medRxiv. 2020. https://doi.org/10.1101/2020.03.02.20029975.

204. Yang-Hartwich Y, Gurrea-Soteras M, Sumi N, Joo WD, Holmberg JC, Craveiro $\checkmark$, Alvero $A B$, Mor $G$. Ovulation and extra-ovarian origin of ovarian cancer. Sci Rep. 2014;4:6116. https://doi.org/10.1038/srep06116.

205. Yao Z, Keeney M, Lin TH, Pajarinen J, Barcay K, Waters H, Egashira K, Yang F, Goodman S. Mutant monocyte chemoattractant protein 1 protein attenuates migration of and inflammatory cytokine release by macrophages exposed to orthopedic implant wear particles. J Biomed Mater Res A. 2014; 102:3291-7. https://doi.org/10.1002/jbm.a.34981.

206. Yoon HE, Kim EN, Kim MY, Lim JH, Jang I, Ban TH, Shin SJ, Park CW, Chang YS, Choi BS. Age-associated changes in the vascular renin-angiotensin system in mice. Oxid Med Cell Longev. 2016;2016:6731093. https://doi.org/1 $0.1155 / 2016 / 6731093$.

207. Yu C, Dou T, Liu Y, Liu R. Clinical value of TV-CDS combined with serum tumor markers in diagnosis of ovarian cancer. Oncol Lett. 2020a;20:2028-34. https://doi.org/10.3892/ol.2020.11705.

208. Yu J, Ouyang W, Chua MLK, Xie C. SARS-CoV-2 transmission in patients with cancer at a tertiary care hospital in Wuhan, China. JAMA Oncol. 2020b;6: 1108-10. https://doi.org/10.1001/jamaoncol.2020.0980.

209. Yu X, Cui L, Hou F, Liu X, Wang Y, Wen Y, Chi C, Li C, Liu R, Yin C. Angiotensin-converting enzyme 2-angiotensin (1-7)-Mas axis prevents pancreatic acinar cell inflammatory response via inhibition of the p38 mitogen-activated protein kinase/nuclear factor-kB pathway. Int J Mol Med. 2018;41:409-20. https://doi.org/10.3892/ijmm.2017.3252.

210. Yun H, Sun Z, Wu J, Tang A, Hu M, Xiang Z. Laboratory data analysis of novel coronavirus (COVID-19) screening in 2510 patients. Clin Chim Acta. 2020;507:94-7. https://doi.org/10.1016/j.cca.2020.04.018.

211. Zhang Q, Yu S, Lam MM, Poon TC, Sun L, Jiao Y, Wong AS, Lee LT. Angiotensin II promotes ovarian cancer spheroid formation and metastasis by upregulation of lipid desaturation and suppression of endoplasmic reticulum stress. J Exp Clin Cancer Res. 2019;38:116. https://doi.org/10.1186/ s13046-019-1127-X.

212. Zheng HY, Zhang $M$, Yang $C X$, Zhang $N$, Wang $X C$, Yang $X P$, Dong $X Q$, Zheng $Y T$. Elevated exhaustion levels and reduced functional diversity of $T$ cells in peripheral blood may predict severe progression in COVID-19 patients. Cell Mol Immunol. 2020;17:541-3. https:/doi.org/10.1038/s41423-020-0401-3.

213. Zheng J, Shi Y, Xiong L, Zhang W, Li Y, Gibson PG, Simpson JL, Zhang C, Lu J, Sai J, Wang G. The expression of IL-6, TNF-a, and MCP-1 in respiratory viral 
infection in acute exacerbations of chronic obstructive pulmonary disease. J Immunol Res. 2017:2017:8539294. https://doi.org/10.1155/2017/8539294.

214. Zhou Y, Fu B, Zheng X, Wang D, Zhao C, Qi Y, Sun R, Tian Z, Xu X, Wei H. Pathogenic T-cells and inflammatory monocytes incite inflammatory storms in severe COVID-19 patients. Natl Sci Rev. 2020:nwaa041. https://doi.org/10.1 093/nsr/nwaa041.

215. Zhuang MW, Cheng Y, Zhang J, Jiang XM, Wang L, Deng J, Wang PH. Increasing host cellular receptor-angiotensin-converting enzyme 2 (ACE2) expression by coronavirus may facilitate 2019-nCoV (or SARS-CoV-2) infection. J Med Virol. 2020. https://doi.org/10.1002/jmv.26139.

216. Zimpelmann J, Burns KD. Angiotensin-(1-7) activates growth-stimulatory pathways in human mesangial cells. Am J Physiol Renal Physiol. 2009;296: F337-46. https://doi.org/10.1152/ajprenal.90437.2008.

\section{Publisher's Note}

Springer Nature remains neutral with regard to jurisdictional claims in published maps and institutional affiliations.

Ready to submit your research? Choose BMC and benefit from:

- fast, convenient online submission

- thorough peer review by experienced researchers in your field

- rapid publication on acceptance

- support for research data, including large and complex data types

- gold Open Access which fosters wider collaboration and increased citations

- maximum visibility for your research: over $100 \mathrm{M}$ website views per year

At BMC, research is always in progress.

Learn more biomedcentral.com/submissions 